University of Nebraska - Lincoln

DigitalCommons@University of Nebraska - Lincoln

1996

\title{
A General Protocol for Restoration of Regulated Rivers
}

Jack A. Stanford

University of Montana

J. V. Ward

EAWAG/ETH

William J. Liss

Oregon State University

Christopher A. Frissell

University of Montana

Richard N. Williams

See next page for additional authors

Follow this and additional works at: https://digitalcommons.unl.edu/usdoepub

Part of the Bioresource and Agricultural Engineering Commons

Stanford, Jack A.; Ward, J. V.; Liss, William J.; Frissell, Christopher A.; Williams, Richard N.; Lichatowich, James A.; and Coutant, Charles C., "A General Protocol for Restoration of Regulated Rivers" (1996). US Department of Energy Publications. 43.

https://digitalcommons.unl.edu/usdoepub/43

This Article is brought to you for free and open access by the U.S. Department of Energy at DigitalCommons@University of Nebraska - Lincoln. It has been accepted for inclusion in US Department of Energy Publications by an authorized administrator of DigitalCommons@University of Nebraska - Lincoln. 


\section{Authors}

Jack A. Stanford, J. V. Ward, William J. Liss, Christopher A. Frissell, Richard N. Williams, James A. Lichatowich, and Charles C. Coutant 


\title{
A GENERAL PROTOCOL FOR RESTORATION OF REGULATED RIVERS
}

\author{
JACK A. STANFORD \\ Flathead Lake Biological Station. The University of Montana, Polson, MT 59860, USA \\ J. V. WARD \\ Department of Limnology, EAWAG/ETH, Uberlandstrasse 133, CH-8600 Dubendorf. Switzerland \\ WILLIAM J. LISS \\ Department of Fisheries and Wildlife, Oregon State University, Corvallis, OR 97331, USA \\ CHRISTOPHER A. FRISSELL \\ Flathead Lake Biological Station, The University of Montana, Polson, MT 59860, USA \\ RICHARD N. WILLIAMS \\ 510 Clear Creek Drive, Meridian, ID 83642, USA \\ JAMES A. LICHATOWICH \\ 182 Dory Road, Sequim, WA 98382, USA \\ AND \\ CHARLES C. COUTANT \\ Oak Ridge National Laboratory, Box 2008, Oak Ridge, TN 37831, USA
}

\begin{abstract}
Large catchment basins may be viewed as ecosystems in which natural and cultural attributes interact. Contemporary river ecology emphasizes the four-dimensional nature of the river continuum and the propensity for riverine biodiversity and bioproduction to be largely controlled by habitat maintenance processes, such as cut and fill alluviation mediated by catchment water yield. Stream regulation reduces annual flow amplitude, increases baseflow variation and changes temperature, mass transport and other important biophysical patterns and attributes. As a result, ecological connectivity between upstream and downstream reaches and between channels, ground waters and floodplains may be severed. Native biodiversity and bioproduction usually are reduced or changed and non-native biota proliferate.

Regulated rivers regain normative attributes as distance from the dam increases and in relation to the mode of dam operation. Therefore, dam operations can be used to restructure altered temperature and flow regimes which, coupled with pollution abatement and management of non-native biota, enables natural processes to restore damaged habitats along the river's course. The expectation is recovery of depressed populations of native species. The protocol requires: restoring peak flows needed to reconnect and periodically reconfigure channel and floodplain habitats; stabilizing baseflows to revitalize food-webs in shallow water habitats; reconstituting seasonal temperature patterns (e.g. by construction of depth selective withdrawal systems on storage dams); maximizing dam passage to allow recovery of fish metapopulation structure; instituting a management belief system that relies upon natural habitat restoration and maintenance, as opposed to artificial propagation, installation of artificial instream structures (river engineering) and predator control; and, practising adaptive ecosystem management.

Our restoration protocol should be viewed as an hypothesis derived from the principles of river ecology. Although restoration to aboriginal state is not expected, nor necessarily desired, recovering some large portion of the lost capacity to sustain native biodiversity and bioproduction is possible by management for processes that maintain normative habitat conditions. The cost may be less than expected because the river can do most of the work.
\end{abstract}

KEY WORDS: restoration; general protocol 


\section{INTRODUCTION}

Flow regulation is perhaps the most pervasive change wrought by humans on rivers world-wide. Dynesius and Nilsson (1994) recently showed that all of the larger rivers in the northern third of the world are regulated; flow in most is totally controlled by dams and diversions, except for some free-flowing reaches and during extreme floods.

Much research in stream ecology world-wide is now devoted to understanding and mitigating flow regulation and the interactive effects of land and water use by humans within catchment basins. A primary goal of 'The Freshwater Imperative', a recent synthesis of research direction by limnologists in the USA, is understanding and predicting the influences of flow regulation on the integrity (e.g. long-term maintenance of native species diversity) and resiliency (e.g. natural recovery from human-mediated environmental change) of epicontinental aquatic ecosystems (Naiman et al., 1995a; summarized in Naiman et al., 1995b).

River corridors were the arteries for the development of ancient civilizations and modern societies and they remain central to local and global economies. Quality of life in all countries can be assessed in terms of quality and quantity of environmental goods (e.g. potable and irrigable water, fisheries) and services (e.g. sustained discharge and bioproduction) that humans are able to obtain from river ecosystems (sensu Lubchenco et al., 1991). Conservation and restoration of rivers clearly should be a national priority for responsible governments and a wide array of actions have been proposed or discussed (e.g. Gore, 1985; Toth et al., 1993; Gore and F. D. Shields, 1995; Shuman, 1995; Van Dijk et al., 1995).

However, governments struggle with the designation of the specific elements of river environments that need to be conserved or restored, because of conflict between human use of riverine goods and services and different perceptions of how those finite resources can be sustained as human populations burgeon. Moreover, management actions targeted at a particular segment or species too often fail to meet objectives because rivers are not viewed as interconnected ecosystems from headwaters to ocean confluence.

Indeed, a strong tendency has emerged to focus river conservation and restoration on charismatic or economically important fauna, such as trout and salmon, without thorough consideration of the attributes and processes of the catchment that control biodiversity and bioproduction (Sparks, 1995). In the USA, federal legislation aimed at recovery of species deemed in danger of extinction has fostered management and research emphasis on the biology of particular organisms rather than on the ecosystem processes that control their survival within diverse assemblages of native biota (Minckley and Deacon, 1991). For example, the decade-old restoration programme for anadromous salmon runs in the Columbia River has cost well over $\$ 1$ billion dollars; yet, native populations are rapidly approaching non-viable levels (Nehlsen et al., 1991, Huntington et al., 1996) because restoration focused on hatchery production as mitigation for lost or damaged habitat (National Research Council, 1995).

To be successful, river restoration plans must be based not only on the biology of organisms, but also on a thorough understanding of the biogeochemical processes that control the distribution and production of biota, and the human influences on those processes. In this paper we examine the general principles of river ecology and stream regulation in an ecosystem context and we use these principles as the basis for the proposition of a general protocol for restoration of entire catchments.

\section{NATURAL-CULTURAL ELEMENTS OF CATCHMENT ECOSYSTEMS}

Rivers cannot be separated in theory or practice from the lands they drain (Hynes, 1975). Hence, the catchment basin (often referred to as watershed in the USA) defines the spatial dimensions of river ecosystems. Understanding the linkages between terrestrial and aquatic components and processes within the catchment is essential to river protection and restoration.

The catchment landscape is composed of interactive, biophysical resources (e.g. water, minerals, nutrients, habitats, food-webs) that are used by the assemblage of animals and plants (biodiversity) that live within the ecosystem. Biodiversity encompasses such phenomena as genetic variation, morphological variation, life history variation within species and the richness, distributions, biomass and productivity 
of populations, species, guilds and other taxonomic and trophic categories across the landscape. It also encompasses the myriad of biophysical processes (functional attributes) that control these phenomena (Hall et al., 1992; Doppelt et al., 1993; Noss and Cooperrider, 1994; and many others). However, the salient features of biodiversity, species numbers (alpha diversity) and distribution (beta diversity), are determined by the availability of the resources that are needed by animals and plants in order to reproduce successfully (i.e. complete their life cycle) (Andrewartha and Birch, 1954) and thereby sustain ecosystem integrity (Frissell and Bayles, 1996; Ward, in press). Life history stages are determined by the genome of each species as derived from its legacy of genetic responses to changes in the availability of resources. Hence, the dynamic biophysical components of the landscape are controlled in space and time by environmental changes (e.g. forest fires, spates, drought, disease, earthquakes) that vary in intensity and duration.

Similarly, human societies within catchments usually are derived from a mix of cultures (e.g. natives, immigrants) that use or market goods and services to produce wealth or some other measure of the quality of life desired by individuals. Desires and perceptions that individuals have about life-style are dynamic and influenced by heritage, education, earning power, shortages and surpluses of goods such as fossil fuels, laws, taxes and natural resource management policies, among many other social and economic concerns.

The point is, that both natural and cultural components of catchments are complex and highly interactive. Humans change catchment landscapes by using or extracting environmental goods and services; whereas, societies change in relation to the quality or ecological integrity of landscapes in which they reside (Blikie and Brookfield, 1987; Schinberg and Gould, 1994; and many others in the rapidly expanding environmental sociology and ecological economics literature).

Within this natural-cultural framework, we recognize that river ecosystems have a certain natural capacity to maintain biota and produce biomass (Warren et al., 1979; Frissell et al. 1996; Ebersole et al., in press) and that biodiversity and bioproduction are dynamic in time and space in relation to availability of resources (Benke et al., 1988). Biotic dynamics derive from natural variation in the environmental setting; equilibrium conditions (e.g. logistic relationship between resources and bioproduction) rarely exist for very long because environmental changes are constantly reconfiguring resource availability. Periodic constraints on speciesspecific productivity increases opportunities for other species to use resources, inferring that levels of ecosystem biodiversity and bioproduction generally are related to the intensity, frequency and duration of disturbance events (Huston, 1979; Resh et al., 1988; Pimm, 1991; Huston, 1994; Reice, 1994).

Ecological capacity, therefore, varies from place to place and higher levels of biological richness (speciosity) and bioproduction are most likely to occur in ecosystems with a long legacy of high spatial and temporal environmental heterogeneity (Connell, 1978; Ward and Stanford, 1983; Salo et al., 1986; Poff and Ward, 1990; Ward, in press). In contrast, total unit area biomass (standing crop) of a few species, while also constrained by inherent ecosystem capacity, may be high under sustained conditions of environmental constancy owing to slow turnover rates. For example, a few species are often extremely abundant and persistent in spring-brooks, lake outlets and reservoir tailwaters, where disturbance events are relatively benign (e.g. scouring floods, very dynamic diel and annual temperature patterns and rapid changes in transport of particulate matter do not occur because of the buffering effect of the lake or reservior) (Ward and Dufford, 1979; Gislason, 1985; Perry and Sheldon, 1986; Valett and Stanford, 1987; Wooton, 1987; Shannon et al., 1994).

Humans tend to dominate ecosystems, thereby superimposing pervasive, continual perturbation on the natural disturbance regimes that sustain habitats and biotic communities. The result is suppression, and in some cases permanent loss, of environmental heterogeneity and biodiversity, fundamentally reducing the productive capacity of biotic resources (Warren and Liss, 1980; Frissell et al., 1993; Frissell et al., in press; Ebersole et al., in press). The goal of river restoration should be to minimize human-mediated constraints, thereby allowing natural re-expression of productive capacity. In some, if not most, intensely regulated rivers, human-mediated constraints may have progressed to the point that full re-expression of capacity is neither desired nor possible. Nonetheless, the implication is that basic ecological principles applied to rivers in a natural-cultural context can lead to restoration of biodiversity and bioproduction in space and time; but, the constraints must be removed, not mitigated. 


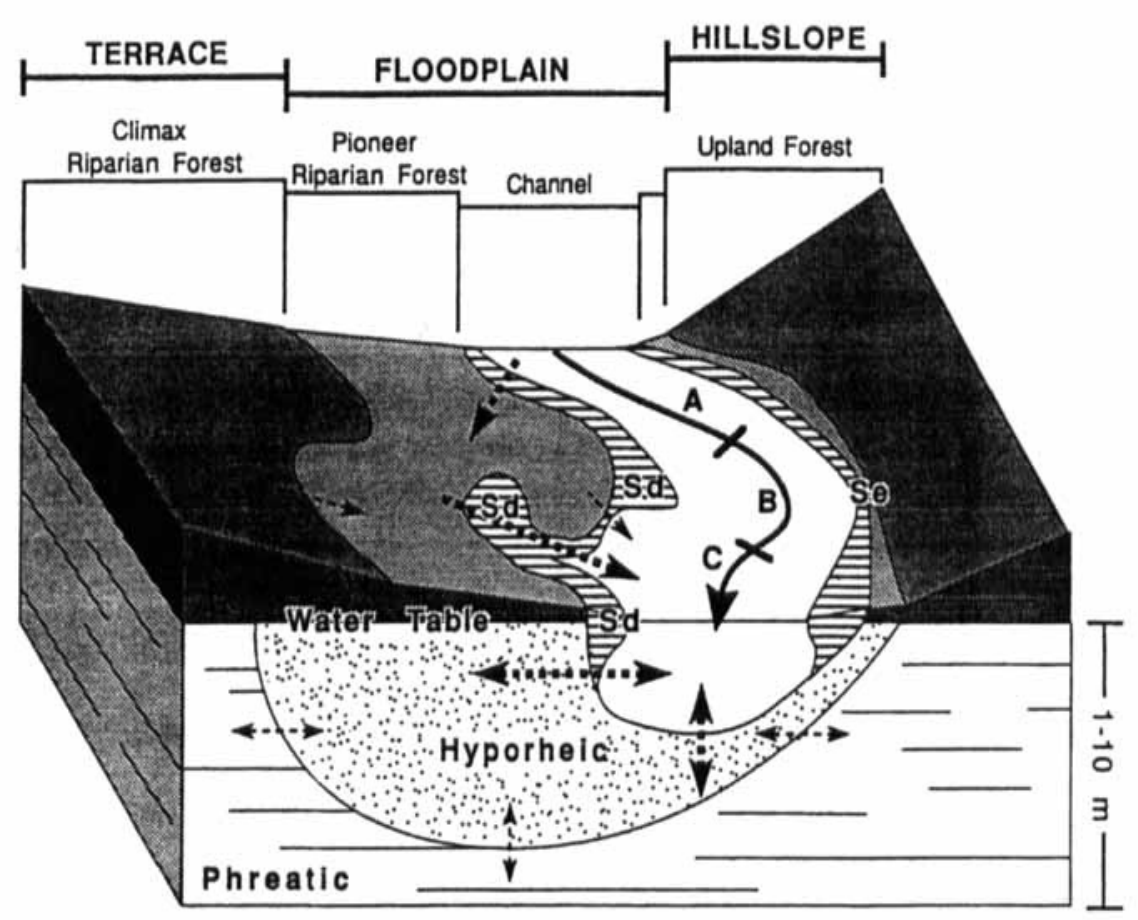

Figure 1. Major landscape features of a montane floodplain river, showing the three primary spatial dimensions (lateral, longitudinal or altitudinal, and vertical) that are dynamically molded through time (the fourth dimension) by fluvial processes. Biota may reside in all three spatial dimensions: riparos (streamside or riparian), benthos (channel), hyporheos (river-influenced groundwater) and phreatos (deep groundwater). The hatched area is the varial zone or the area of the channel that is periodically dewatered as a consequence of the average amplitude of the discharge regime. Major channel features include a run (A), riffle (B) and pool (C); Sd refers to sites of sediment deposition and Se refers to a major site of bank erosion. The heavy solid line is the thalweg and broken lines conceptualize circulation of water between benthic, hyporheic and phreatic habitats (after Stanford, 1996; see also Stanford and Ward, 1992)

\section{GENERAL PRINCIPLES OF RIVER ECOLOGY}

Conservation and management strategies for large rivers must have a solid conceptual basis or they will likely fail to sustain biodiversity and bioproduction. Contemporary river ecology is guided by a number of intertwined concepts or principles derived from empirical studies. No two rivers are exactly alike and no single theory encompasses the myriad of biophysical interactions and responses to natural and human disturbances that make each river unique. However, fundamental principles do apply; many conservaiion and restoration efforts become myopic, costly and too often fail because plans and actions overlook ecological fundamentals.

Unregulated rivers exist as geohydraulic continua from continental divides to the oceans. They are networks of surface and groundwater flow paths that drain catchment landscapes (Gibert et al., 1990). The energy of flowing water constantly reconfigures the physical form of these interconnected flow pathways, primarily by the process of cut and fill alluviation (Leopold et al., 1964) although dissolution can dominate in limestone massifs (Mangin, 1994) and a few other situations. Inorganic and organic materials are eroded upstream and deposited downstream primarily in relation to: (a) long- and short-term flow dynamics; (b) the resistivity of geological formations to erosion and dissolution; (c) instream retention structures (e.g. eddies, wood debris); and, (d) the geometry of the catchment.

Channel morphologies are determined by the legacy of flooding. Big floods fill channels with inorganic and organic materials eroded laterally and vertically at upstream locations, thereby producing a continuum of instream structures (pools, runs, riffles, gravel bars, avulsion channels, islands, debris jams) and lateral floodplain terraces in many sizes and shapes. Local morphologies resulting from infrequent, very large floods may persist in the same general form (quasi-equilibrium) for long time periods until the next big flood, even 

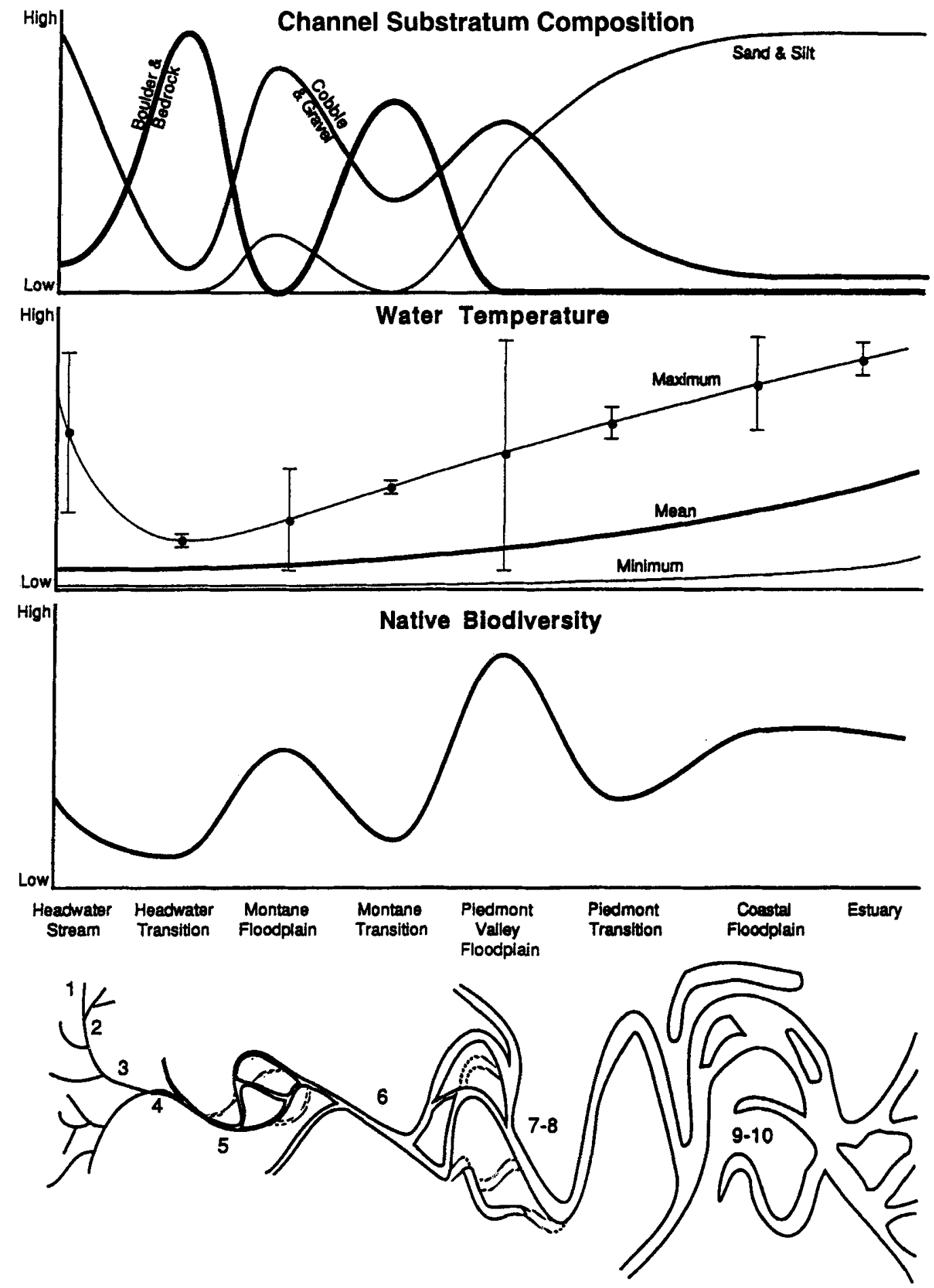

Figure 2. Conceptualized continuum of a large unregulated river showing biophysical gradients and nodes of environmental heterogeneity (centres of organization) of the major alluvial reaches. Vertical bars on the plot of maximum temperature represent the annual range of annual maximum temperature across all habitats at any point in the river continuum. Numbers indicate stream order. The figure is not drawn to scale; transition reaches are often much longer than inferred 
though interim flow dynamics gradually and subtly reconfigure instream structures and features (Schumm and Lichty, 1956). For example, the channel of the Snake River upstream from Hells Canyon, Idaho, USA, persists as an incised gravelbed channel containing a chain of elevated, mid-channel islands that have not been overtopped since the cataclysmic glacial flood that formed them receded over 8000 years ago (Connor, 1993). Other river channels with a greater sediment supply and frequent overbank flooding are constantly shifting, braiding or meandering on the valley bottom from year to year as the channel fills with material in one place causing the flow pathway to avulse and downcut (Best and Bristow, 1993).

All rivers are fundamentally alluvial in nature as a consequence of cut and fill alluviation mediated by flooding. Most rivers have deeply bedded and expansive floodplains interspersed between constrained and often incised reaches (canyons), where the bedrock may be very near or exposed on the stream bottom. Hence, river ecosystems have three important spatial dimensions that are temporally dynamic (Figure 1). The longitudinal (upstream-downstream) dimension is described in detail in the ecological literature, including the occurrence and ecological significance (discussed below) of streamside (riparian) vegetation and associated faunal assemblages in the surficial transition zone from riverine to terrestrial environments. However, critically important lateral and vertical attributes and connections are often overlooked or ignored. Owing to the high porosity of the bed sediments in gravel bed rivers, river water penetrates the bottom and saturates the alluvial bedding of the channel and floodplain down to the less porous bedrock, thereby creating complex groundwater (hyporheic) habitats. As the valley constricts, or owing to changes in the local bedrock geometry, the water table may intersect the surface creating floodplain (riparian) wetlands; permanent springbrooks and ponds in up-welling areas may be observed at the downstream end of flood plains. Indeed, a prominent feature of alluvial rivers is sequential down- and up-welling of river water into and out of the bed sediments, which interacts with overland flooding to create complex habitat mosaics on the floodplain surface. The floodplain, with its hyporheic and riparian habitats, is therefore the transition zone or ecotone linking aquatic and terrestrial components of the river ecosystem above and below ground level. Also, groundwater flowing from uplands may mix with river water flowing within the hyporheic zone, creating yet another important lateral ecotone. These lateral and vertical transition zones alternate in juxtaposition with the channel from headwaters to mouth, forming hyporheic and riparian corridors (Naiman et al., 1988; Stanford and Ward, 1993; Ward and Weins, in press).

The mosaic of channel and floodplain structures creates a constantly changing habitat template (sensu Southwood, 1977, 1978) for a myriad of plants and animals that comprise riverine food-webs. Resources needed by particular life history stages of organisms have discrete or 'patchy' distributions within this heterogeneous landscape. As flows change, not only does the ability of the river to move substratum change, but the way in which water moves around and/or over instream structures, such as boulders and gravel bars, also changes. Hence, biota must adapt to resources arrayed as dynamic patches that manifest from local (e.g., a single rock on a single riffle in a particular river reach: Townsend, 1989) to catchment scale. Moreover, as biota attempt to find and utilize these patches to sustain growth and reproduction over the long term, they must also adapt to the physical forces of water movement (Statzner et al., 1988). Therefore, biota are often arrayed in precise locations within the river channel and along the river continuum (Poff and Allan, 1995). For example, a large, behaviourally dominant trout may occupy the optimal position within an eddy for capturing drifting insects; if that fish is removed, the next fish in the pecking order will move into that foraging location (Bachman, 1983). Salmonids are generally confined to the colder, rocky reaches (rhithron) of the stream continuum and are replaced by warm water species (e.g. cyprinids, ictalurids) in the slow moving, sandy and often turbid reaches downstream (potamon) (Illies, 1956; Illies and Botosaneanu, 1963).

The river continuum is a complex, dynamic gradient of habitat types from headwaters to oceanic confluence, and flora and fauna are usually distributed rather predictably along that gradient (Figure 2) according to the requirements specified by each stage in their life cycle (Vannote et al., 1980). Each species or unique life history type (stock or population) is most abundant where the resources they require are most abundant and/ or most efficiently obtained. They will be present (locally adapted) wherever they can maintain a positive energy balance, that is, they have enough resources to sustain growth and reproduction and thereby sustain the presence of the species or stock in the river food-web at that location (Hall et al., 1992). For some species, a positive life history energy balance can be maintained without much movement and suites of organisms 
appear to occur in zones along the river continuum; others must move long distances in search of resources needed for each life stage, sometimes involving migrations into the lakes (c.g. adfluvial bull charr, Salvelinus confluentus) or the ocean (e.g. anadromous salmon and trout: Onchorynchus spp.; Salmo salar and S. trutta; Salvelinus spp.).

Widely dispersed species often exist as metapopulations because local populations are linked by dispersal and gene flow into larger regional populations that may encompass the entire catchment (Hanski, 1991; Hanski and Gilpin, 1991). For example, metapopulation structure is thought to be particularly evident in many salmonid populations (Reisenbichler et al., 1992; Rieman and McIntyre, 1993) and most likely influences the probability of persistence for a species (Stacy and Taper, 1992). Metapopulation linkages allow for local extinction of populations, which can be re-established via colonization from adjacent populations (Leider, 1989; Milner and Bailey, 1989). The spatial arrangement of large- and small-scale habitat features within a catchment may serve as a template for metapopulation organization of fishes (Schlosser and Angermeier, 1995). The mosaic of floodplain reaches and constrained segments (Figure 2) within the mainstem and tributaries influences size, spatial distribution and proximity of local spawning populations. Proximity of populations and favourability of connecting habitats can affect exchange of individuals between local populations (Reiman and McIntyre, 1993; Li et al., 1995; Schlosser and Angermeier, 1995) and thus influence potential for recolonization of habitats where local extinction has occurred.

Since most river fauna are ectotherms, growth and reproduction is also vitally influenced by river temperature. Most organisms adapted to the cold climes of the headwater reaches simply cannot survive in warmer reaches downstream, and vice versa. Indeed, species found in a particular thermal environment in one river generally will be found in very similar environments in other rivers within the geographical range of that species, if all other resource needs are also met. Because growth of ectotherms is strictly temperature dependent, temperature is a critical habitat attribute (Ward, 1985; Hall et al., 1992). Stream insects and fish will be found in areas of the stream where their thermal needs are met and substratum, food and other resources are marginal, but rarely the inverse, at least for individuals that ultimately reproduce successfully. This is because of the basic thermal energetics of growth and the fact that many life history stages, such as insect emergence (ecdysis) and fish spawning are initiated by precise temperature cues (Brett, 1971; Vannote and Sweeney, 1980; Ward and Stanford, 1982). In addition, because few riverine organisms have highly specialized food requirements, food limitation may be less prevalent than thermal limitation most of the time.

For plants of the river food-web, availability of light and nutrients is crucial. In headwater streams shaded by riparian plants, decomposition of allochthonous (terrestrially derived) coarse particulate organic matter (leaves, grasses) usually drives instream bioproduction (Cummins et al., 1984, 1989). Plant growth nutrients are released into transport by the decomposition of particulate organic matter entrained on the bottom, and are utilized by aquatic plants in better light environments downstream where the stream channel is wider and the riparian canopy opens. Of course, nutrients and other dissolved solids are also derived from dissolution of the bedrock and other geochemical reactions. Indeed, streams with high alkalinity from limestone dissolution generally are more productive than streams draining more inert bedrocks, such as granite massifs (Kruger et al., 1983; Waters et al., 1990). Dissolved solids that are required for growth by algae and macrophytes spiral downstream, alternatively retained and released into transport by the river food-webs (Newbold et al., 1981, 1982). Conditions may shift back to heterotrophy in turbid, slow moving reaches near the river mouth as a consequence of planktonic microbial decomposition of organic matter transported from upstream reaches, reduced light reaching the bottom owing to deep and often turbid water and shifting substratum (Vannote and Sweeney, 1980; Minshall et al., 1983; Naiman et al., 1987).

All of this underscores the complex linkages between the spatial dimensions of river ecosystems (Figure 1). These interactive components and attributes are repeated throughout the river course, from headwaters to mouth. Floods maintain channel and floodplain habitats and pulse nutrient-enriched waters laterally into backwaters and on to floodplains, as well as downstream into the estuary. Because it is a continual habitat-forming process, river biota are adapted to frequency and duration of flood pulses (Copp, 1989; Junk et al., 1989). Rivers that flood frequently (annually or more often) maintain different species and foodwebs than systems that are more ecologically benign by rarely or never experiencing scouring floods (e.g. spring-brooks and lake outlet streams). Food-webs are complex and change predictably along the stream 


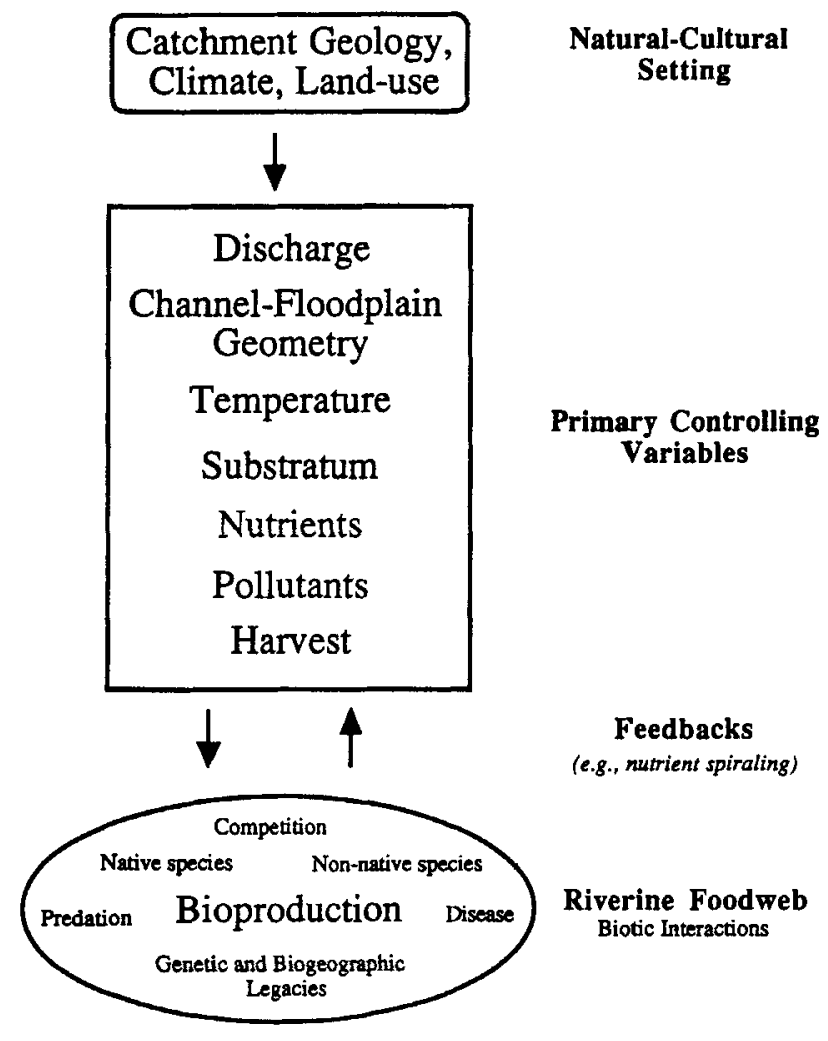

Figure 3. Primary controlling variables and biophysical interactions of river ecosystems

continuum in direct response to variations in the strength of interconnections between channel, groundwater, floodplain and upland elements of the catchment (Ward and Stanford, 1995a).

In our view the primary variables driving the distribution and abundance of animals and plants in flood prone rivers are usually abiotic and primarily determined by the geological and climatic setting of the catchment basin (Figure 3). Biotic interactions (e.g. competition, predation, parasitism), while they obviously continually occur within food-webs in all habitats, may become progressively more important and apparent as the time between abiotic disturbances increases, and hence are most pronounced in spring-brooks and lake outlet streams where abiotic drivers are comparatively non-variable (Ward and Stanford, 1983b; McAuliffe, 1983, 1984; Reice, 1994). All big rivers that are not influenced by large on-channel lakes are naturally flood prone, and ultimately biophysical structure is controlled by the inexorable, but highly dynamic, scouring process of cut and fill alluviation.

Environmental heterogeneity (complexity) maximizes in the alluvial (aggraded) reaches of the river continuum. Owing to the energetics of materials transport through large catchment basins from high elevation to sea level, alluvial reaches are arrayed along the stream continuum between canyon segments like beads on a string (Figure 2). The hyporheic and riparian corridor is expansive on alluvial reaches and seasonal temperature patterns vary within the wide array of aquatic habitats that exist laterally from the channel across the floodplain (Ward, 1984). Large floodplains appear to function as centres of biophysical organization within the river continuum (sensu Regier et al., 1989). They are likely to be 'hot spots' of biodiversity and bioproduction that are structurally and functionally linked by the river corridor (Copp, 1989; Gregory et al., 1991; Zwick, 1992; Stanford and Ward, 1993; Ward and Stanford, 1995a,b). Indeed, intermountain and piedmont valley floodplains world-wide are characterized by nutrient-rich floodplain soils and diverse and productive backwater and mainstem fisheries (Welcomme, 1979; Davies and Walker, 1986; LoweMcConnell, 1987; Sparks et al., 1990; Junk and Piedade, 1994; Welcomme, 1995). These reaches are also 
foci for human activities within the catchment basin (Amoros et al., 1987; Petts et al., 1989; Wissmar et al., 1994).

Additional data are needed to confirm explicitly the pattern of biodiversity hypothesized in Figure 2 for a spectrum of rivers world-wide, but the importance of alluvial zones as biological 'hot spots' within river continua is very clear (e.g. riparian plants: Junk et al., 1989; Gregory et al., 1991; benthic insects: Zwick, 1992; Roth et al., in press; fishes: Welcomme, 1979; Rieman and McIntyre, 1995). Moreover, metapopulation theory suggests that core populations are critical for persistence of metapopulations with core-satellite structures (Schoener 1991; Harrison 1991, 1994). Core populations are relatively large populations occupying high quality habitat. In rivers, large alluvial reaches may support core populations of fishes (Lichatowich and Mobrand, 1995). These productive populations can serve as stable sources of dispersers that can recolonize peripheral habitats where less productive satellite populations have undergone local extinctions (Harrison, 1991, 1994; Reiman and McIntyre 1993; Li et al., 1995; Schlosser and Angermeier, 1995); or, core populations may 'rescue' from extinction satellite populations whose abundance has been severely reduced (Brown and Kodrick-Brown, 1977; Gotelli 1991; Stacey and Taper, 1992). Thus, core populations can buffer metapopulations against environmental change and contribute to resiliency of regional fish production. Certain riparian plant species also appear to exist as metapopulations with cores on alluvial floodplains (Decamps and Tabacchi, 1994). Therefore, we propose that alluvial reaches should also be foci for large river conservation and restoration.

\section{THE RIVER DISCONTINUUM: HUMAN ALTERATION OF LARGE RIVER ECOSYSTEMS}

Humans vastly reduce the capacity of river ecosystems to sustain natural biodiversity and bioproduction by severing or compromising the dynamic interactive pathways of the river continuum. As described above, native biota of rivers display life history traits that allow populations to survive within a certain range of environmental variation that characterizes a particular river. If this range of variation changes, organisms must locally adapt to the new range of environmental conditions or be extirpated. Recolonization of extirpated areas may occur over time as environmental constraints ameliorate and/or as a consequence of immigration of suitably adapted populations. However, human-mediated environmental change can be so rapid and so severe as to exceed the ability of biota to adapt. The interactive pathways of the river continuum too often are permanently severed by human activities, and native biodiversity and bioproduction decline.

Pervasive human perturbations that uncouple important ecological processes linking ecosystem components in large river basins can be lumped into three broad classes: (a) water pollution of all types; (b) food-web manipulation by harvest, stocking and exotic invasions; and (c) alteration of water, temperature and materials flux by dams, diversions and revetment. Human land use creates direct and diffuse inputs of water-borne wastes from the catchment and its airshed (Hynes, 1966; Warren, 1971), accelerates erosion and sediment loading related to deforestation and road building (Waters, 1995), alters flux rates of materials in rivers (e.g. eutrophication, acidification) and uncouples lotic food-webs by toxic effects. Harvest of fishes and invertebrates, and the purposeful and accidental introduction of non-native species, induces strong interactions that alter food-webs by causing biomass and bioproduction shifts, species replacements and other trophic effects (Mooney, 1986) that may cascade through all trophic levels and even involve terrestrial species that feed on aquatic biota (Spencer et al., 1991). Pollution and food-web manipulation are interactive with stream regulation effects in most catchments. However, alteration of flow regimes and associated severing of connectivity in the three spatial dimensions of riverine ecosytems perhaps are the most strikingly pervasive influence of humans on river landscapes world-wide (Dynesius and Nilsson, 1994).

\section{Three first principles of the ecology of stream regulation}

At least three fundamental commonalties emerge from the large literature on the ecology of regulated rivers (reviewed by Baxter, 1977; Ward and Stanford, 1979, 1987; Lillehammer and Saltveit, 1984; Petts, 1989; Calow and Petts, 1992). These principles must be recognized in the derivation of large river restoration strategies.

1. Habitat diversity is substantially reduced. Large storage dams world-wide inundate piedmont or 
(a)
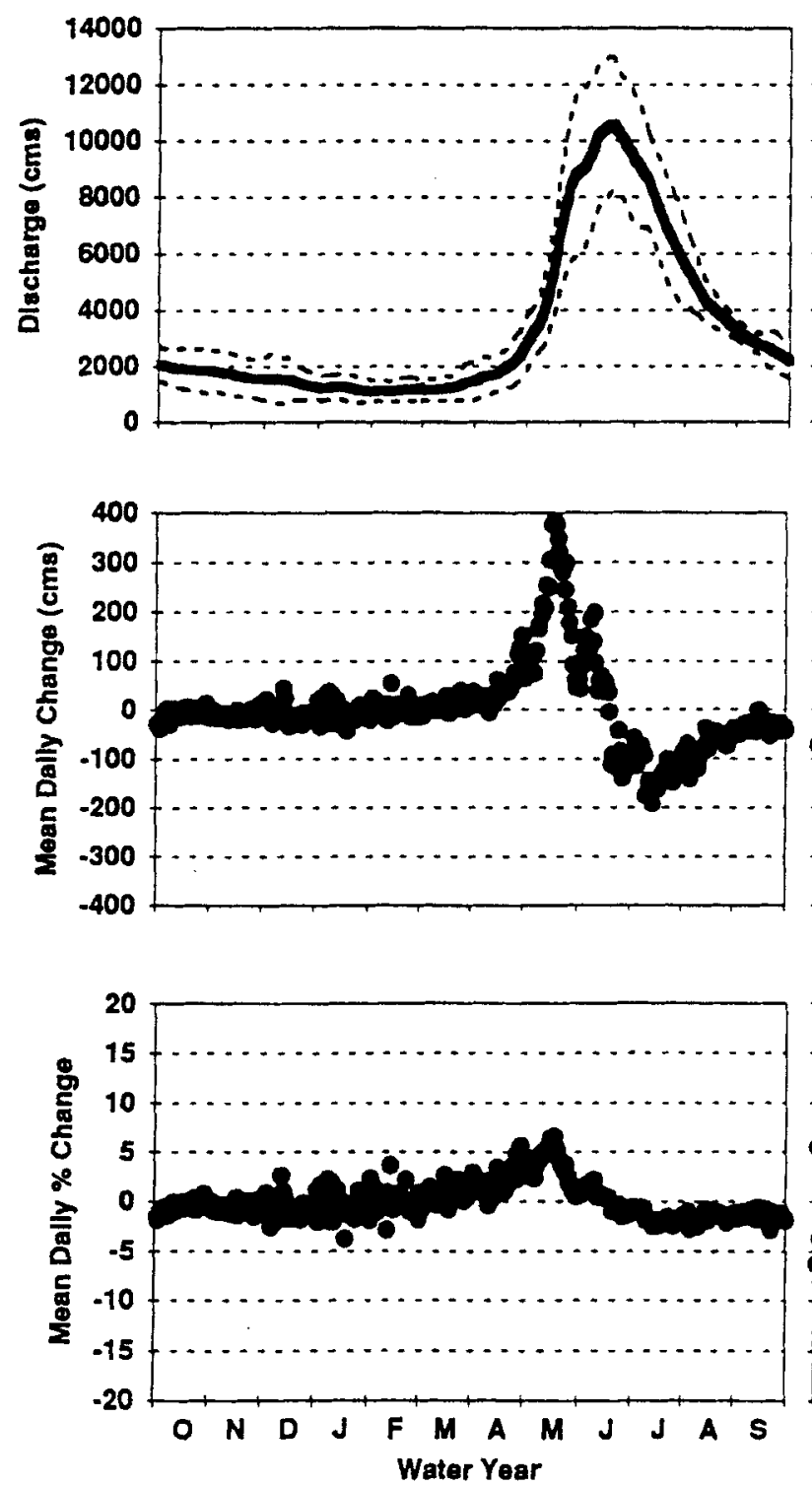

(b)

1983-1992
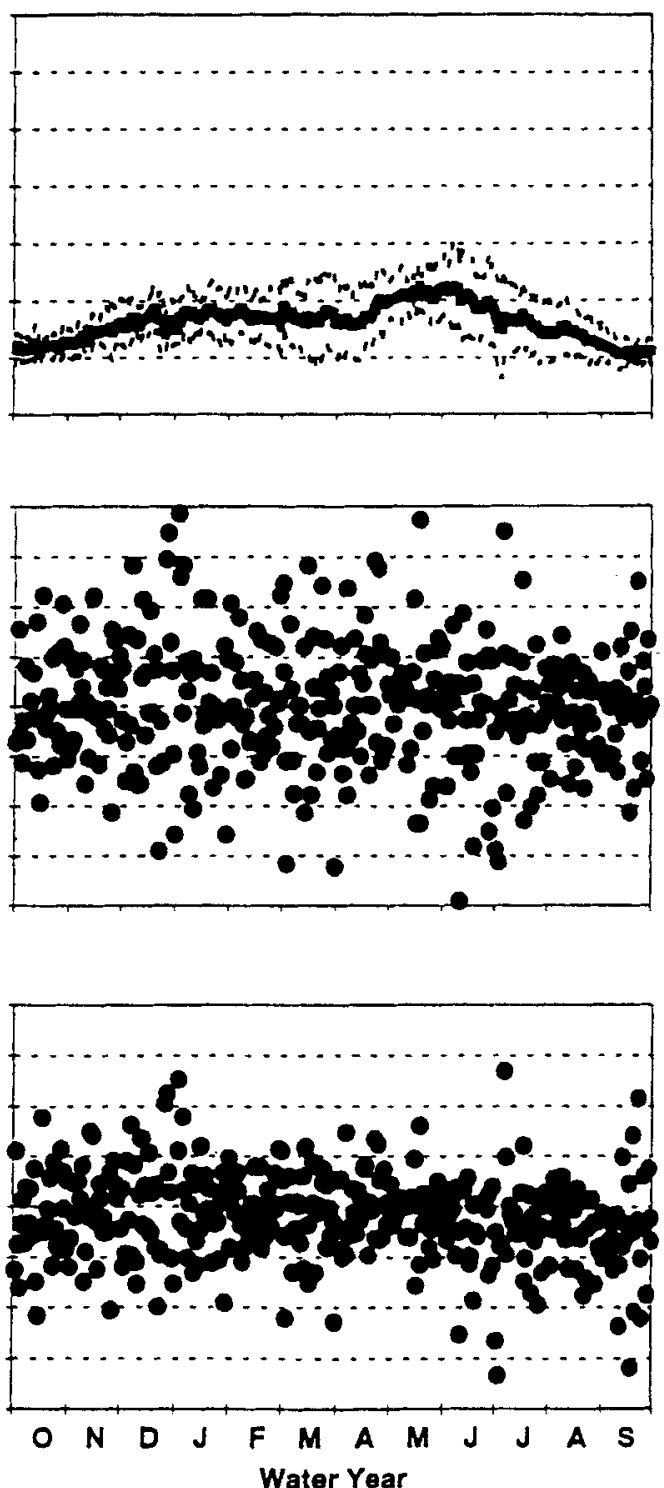

Figure 4. (a) Discharge of the Columbia River, USA, in the Hanford Reach, an eighth-order segment in the piedmont transition (see Figure 2) between Priest Rapids and the confluence of the Snake River, for the period 1920-1929 when no large storage dams were present upstream. In the top panel the solid line is mean daily discharge plotted for each day of the water year beginning 1 October and ending 30 September, and the broken line plots standard error. These data were used to calculate average daily change in discharge (middle panel) and average percentage daily change (bottom panel) (b) Same as (a), except data are for the period 1983-1992, when the flow of the Columbia River in this reach was regulated by Priest Rapids and other dams upstream (derived from US Geological Survey data, Reston. Virginia, USA)

mountain valley floodplains, thereby severing the river continuum. Mass transport dynamics that create instream and floodplain habitats for riverine biota are drastically altered. Flood peaks are eliminated, daily discharges are more variable (e.g. Figure 4) and temperature seasonality may be reduced or lost (Stanford and Hauer, 1992; Blinn et al., 1995). 

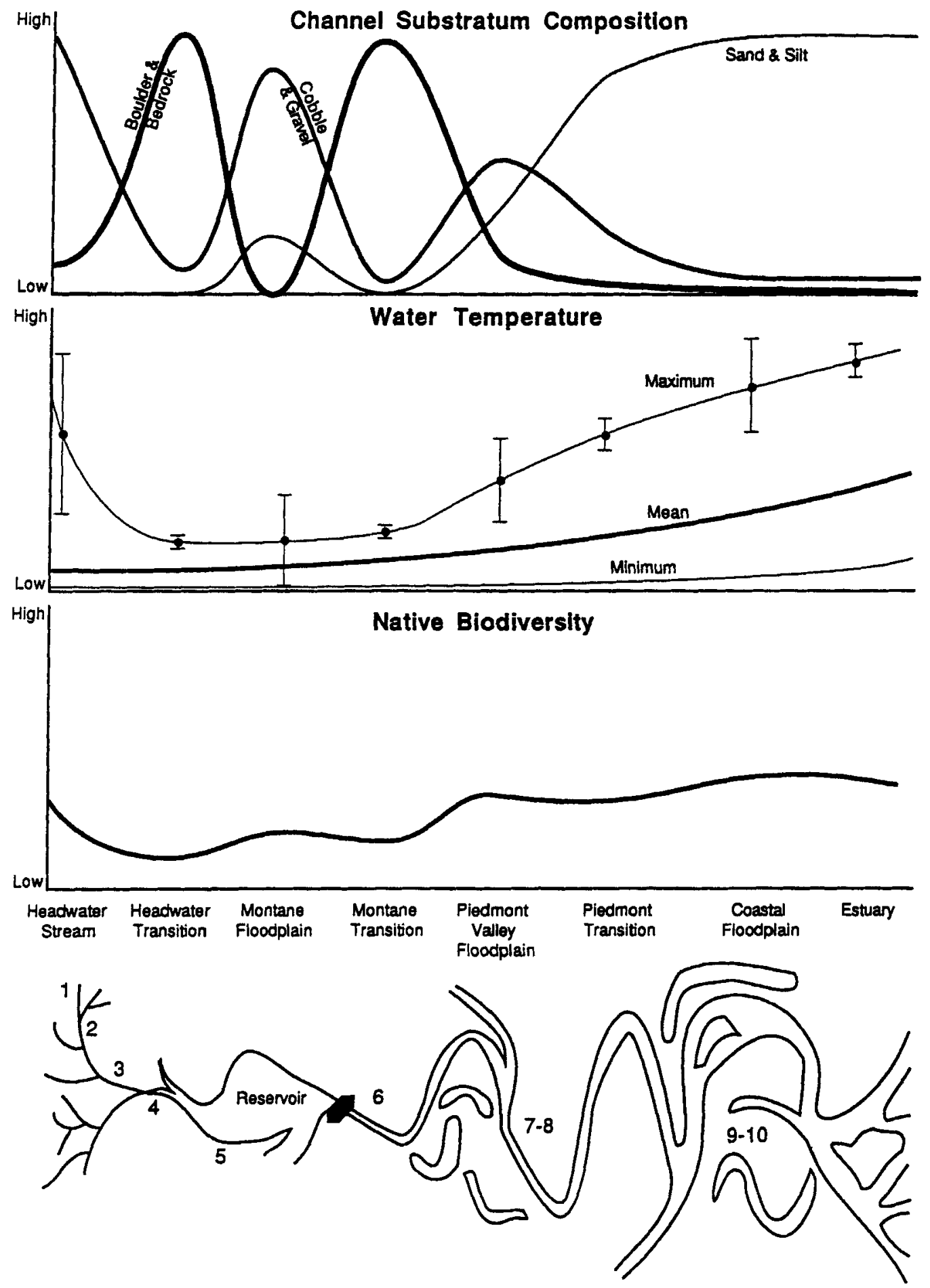

Figure 5. Conceptualized continuum of a large river after regulation by a high volume, high head storage dam in the montane transition (compare with Figure 2). Tributaries downstream from the dam are assumed to be unregulated. Vertical bars on the plot of maximum temperature represent the annual range of annual maximum temperature across all habitats at any point in the river continuum. Numbers indicate stream order. The figure is not drawn to scale; transition reaches are often much longer than inferred 
As a consequence of reservoir storage of peak flows for flood control, navigation, irrigation and hydropower production, baseflows increase substantially and often fluctuate so erratically that aquatic biota cannot survive in shallow, near-shore habitats. The varial zone, shown in Figure 1, constricts owing to loss of peak flows and is depopulated by cyclic dewatering and rewatering that occurs on weekly, daily or even hourly schedules (Cushman, 1985; Jourdonnais and Hauer, 1993). In stark contrast, a natural river pulses water on to often expansive floodplains within a range of variation that allows a diversity of aquatic and riparian biota to exist in multiple successional stages in a complex array of habitats. Persistent shallow or slack water habitats are especially important for the survival of early life history stages of fishes that cannot survive in the strong currents of the channel thalweg. Storage of bedload in the reservoir and constant clear water flushing downstream artificially depletes gravel and finer sediments in the tailwaters, causing armouring of the bed with large cobble and boulder substratum (Simons, 1979). Large rocks eroded from the canyon walls and coarse bedload from tributaries jam the channel and increase the size of rapids over time, because peak flows are insufficient to scour and transport the largest materials downstream (Dolan et al., 1978). Channel constrictions and habitat simplification occur as the channel downcuts and riparian vegetation invades to the top of the varial zone in aggraded reaches, owing to loss of upstream sediment supply and loss of scouring flood flows (Johnson, 1994; Church, 1995).

The general conclusion is that regulation creates a discontinuum of environmental conditions and severs the connectivity of channel, groundwater, floodplain and upland components of the catchment ecosystem; habitats for riverine biota become spatially homogenous, limited to the permanently wetted portion of the channel thalweg that is dominated by conditions dictated by operations of upstream storage reservoirs (Figure 5). Indeed, serial construction of low-head dams has converted virtually all the mainstems of the largest rivers in USA, Europe, Sweden and Finland into shallow reservoir habitat that is neither truly lacustrine nor riverine.

2. Native biodiversity decreases and non-native species proliferate. Native biodiversity almost always decreases after regulation (Minckley and Deacon, 1991; Ward and Stanford, 1991; Moyle and Leidy, 1992; Stevens et al., in press), as conceptualized in Figure 5 compared with Figure 2. Vital core populations may be extirpated and satellite populations may become increasingly isolated by regulation schemes. Moreover, for anadromous species of fish mortality resulting from passage through dams and reservoirs on the mainstem may be selective for certain of the geographically diverse populations that use the mainstem as a common migratory pathway, thereby reducing biodiversity and increasing the probability of metapopulation extinction (Harrison and Quinn, 1989; Reiman and McIntyre, 1993).

Altered temperature patterns and continual export of very fine organic matter and dissolved nutrients, coupled with simplification of the channel, stabilization of bottom substratum and loss of floodplain inundation, promotes environmental conditions to which native species are poorly adapted, opening opportunities for non-native plants and animals to establish robust populations (Stanford and Ward, 1986; Li et al., 1987; Pflieger and Grace, 1987; Bain et al., 1988; Shannon et al., 1994). In some cases one or a few native species are more abundant than they were before regulation (e.g. Poe et al., 1991). But, the most pervasive result of habitat change produced by regulation is the proliferation of non-native species. Non-native invertebrates and fishes are consistently more abundant in regulated compared with unregulated river reaches ( $\mathrm{Li}$ et al., 1987; Bain et al., 1988). Native riparian plants cannot exist on dewatered floodplains, which opens niches for exotic, dryland plants. Moreover, owing to loss of scouring flows, exotic and some native riparian plants choke the periodically saturated area of the shoreline above the narrowed varial zone and exotic hydrophytes usually invade and quickly dominate shallow water habitats (Decamps and Tabacchi, 1994; Johnson, 1994). Explicit reasons for non-native proliferation in regulated rivers vary, but, in general, non-natives are simply better competitors in the homogenous habitats of regulated rivers, plus the fact that a wide array of non-natives have been purposely introduced into regulated rivers.

3. Biophysical conditions reset predictably in relation to influences of tributaries and as distance downstream from the dam increases. The serial discontinuity concept (SDC) (Ward and Stanford, 1983, 1985b) explicitly acknowledges the inherent connectivity of the river continuum and predicts that the conditions described above will ameliorate downstream as a natural consequence of the biophysical energetics of rivers. The spatial rate at which reset occurs and its manifestation relative to position within the river continuum (Figure 5) is related to the limnological attributes (depth, volume, water retention time, trophic state) of 
the reservoir, the mechanics of water release (surface, bottom or depth selective), the mode of dam operations and the influence of tributaries entering downstream from the dam. If the tributaries are large and unregulated, they may substantially mediate the reset (Stanford and Hauer, 1992). In any case, conditions at some point downstream from the dam will closely approximate conditions elsewhere in the continuum. Thus, upstream or downstream shifts in biophysical conditions mediated by dams manifest as predictable discontinuities in the river continuum. For example, biophysical conditions at some predictable point downstream from a large bottom release (hypolimnial) dam in the montane transition of a temperate latitude river will be very similar to pristine conditions far upstream, because of the cool, clear water released from the reservior. In rivers that are free flowing for long distances downstream from large dams in the montane reaches, the position of the rhithron-potomon transition can be predicted from the operational mode of the dams relative to the influence of tributaries.

The predictions of the SDC along the longitudinal dimension have been largely substantiated (Stanford $e t$ al., 1988; Ward and Voelz, 1988; Hauer et al., 1989; Stanford and Ward, 1989; Ward and Stanford, 1990, 1991; Munn and Brusven, 1991; Sabater et al., in press), although recent incorporation of responses of large floodplains (Ward and Stanford, 1995b) require additional resolution. The main point is that the ecological consequences of specific regulation schemes are largely predictable, and environmental degradation associated with regulation can be ameliorated. We recognize that uncertainties derive from interactions with pollution and the introduction of exotic biota. However, pollution can be curtailed or eliminated, and nonnative biota are likely to be substantially less successful as invaders when dams are operated in ways that maximize resets of environmental heterogeneity.

\section{RESTORATION PROTOCOL}

The era of dam building may be over in much of the world because high efficiency and affordable dam sites are already developed. Loss of biodiversity and bioproduction, especially riverine and anadromous fisheries (Frissell, 1993; Welcomme 1995), underscores the need for restoration of regulated rivers and enormously expensive reconstructions are underway or are being planned (Dahm et al., 1995; Gore and Shields, 1995). Even removal of large dams on large rivers is included in some restoration plans because the costs of damage to fisheries and other attributes of riverine integrity in some instances far exceed the commercial value of the dams. Removal of large dams is obviously problematic in a variety of ways, such as the mobilization of large volumes of fine sediments stored in the reservoir basin, and methods for evaluating removal strategies have been proposed (Shuman, 1995). A variety of approaches exist for restoring small streams with substantial emphasis on engineered structures such as weirs, off-channel ponds, rock gardens (Gore and Shields, 1995) and many other artificial habitat structures (Hunter, 1991). Commercial operations advertise engineering expertise for bulldozing damaged streams back to pre-regulation channel configurations and stories of restored fisheries and improved water quality abound in the popular literature, although scientific, long-term evaluations of such schemes are much less available (Sear, 1994). Structures placed instream are often washed out, fail to restore biodiversity or produce unanticipated negative responses, such as increased bank erosion or accelerated deposition of fine sediments (Frissell and Nawa, 1992) and increased water temperatures (C. Frissell, unpublished data) associated with weirs and rock gardens. Such problems largely derive from lack of attention to the conceptual foundations of river ecology and the first principles of the ecology of regulated streams.

\section{Formalize the problem at catchment scale}

Restoration of large, regulated rivers begins with recognition of the river continuum and evaluation of the loss of ecosystem capacity to sustain biodiversity and bioproduction. Biological (e.g. past and present distribution of native biota) and physical (e.g. channel configuration) indices of ecosystem resilience are needed (Frissell et al., 1993); measures of biological integrity as defined by Angermeier and Karr (1994) may be more useful than biodiversity per se because of the difficulty of accurately determining the distribution and abundance of benthos, fish and other river organisms. Habitat requirements for all life history stages and generation times (turnover rates) of native, keystone species (i.e., top carnivores and other 
strong interactors capable of structuring food-webs: Power et al., 1995) may clarify spatial and temporal scales in large river restorations.

In general, the entire catchment, from headwaters to the ocean, is relevant. In the case of rivers that support anadromous fisheries, estuarine and ocean habitats connect functionally to the riverine components. Mathematical models can be used very effectively to formalize understanding of the effects of regulation and interactions with pollution and food-web manipulation within the river continuum, but models should not be used exclusively to define a restoration strategy (Hall, 1988b). The process must be inferential from the entire body of quantitative and qualitative information about how river regulation and interactive effects have altered ecosystem capacity.

\section{Restore environmental (habitat) heterogeneity but let the river do the work}

The main goal is to reduce the range of human disturbances so that interconnected riverine habitats (Figures 1 and 2) can support diverse and productive food-webs, including species of special social and economic interest. Management should strive to restore environmental heterogeneity and reduce or eliminate sources of mortality from pollution and overharvest. Keep in mind that riverine biodiversity and bioproduction are largely controlled by abiotic drivers (Figure 3) and that density-dependent relationships, such as the stockrecruitment relations often used to determine fisheries harvest prescriptions, rarely manifest predictably owing to natural abiotic variation (Hall, 1986; Hall, 1988a; Pimm, 1991; Huston, 1994).

Owing to the importance of flow to habitat maintenance, and temperature to food-web energetics, highly significant restoration is possible simply by reregulation to allow more natural seasonality of flow and temperature. We call this restoration of normative habitat conditions, where the norm or standard is established from what is possible in a natural-cultural context as opposed to striving for pristine conditions which are difficult, if not impossible, to define or achieve, at least for entire catchments. Removal of dams certainly should be considered and, where possible, done; but, restoration of normative habitat conditions is possible in many if not most regulated rivers without taking dams out. However, channel revetments are problematic because the objective is to reconnect channels and floodplains.

Peak flows are needed to scour and rearrange substratum and reconnect floodplain habitats with the channel; spatial and temporal temperature variability promotes re-establishment of native biodiversity (Figures 2 and 5). Peak flows needed to re-establish cut and fill alluviation (called effective flows by geomorphologists) may or may not be equal to bank-full, and gravel supply may be limiting owing to storage of bedload in the reservoirs (Ligon et al., 1995). Effective flows can rapidly degrade (downcut) entire segments when sediment mass balance relations change as a consequence of regulation (Andrews and Nelson, 1989). Adding sediments to regulated rivers (e.g. using slurry pipelines from reservoir deltas) should not be out of the realm of consideration in situations where instream sediment supply is limited by years of regulation. However, overbank flows in many cases will initiate cut and fill alluviation in an ecologically effective manner, supplying sufficient sediment from lateral erosion.

We emphasize that reregulation of flows requires careful evaluation of channel morphometry, bed-sediment size distribution and shear stress in relation to the range of possible flows. A great deal of geomorphological study and modelling has been devoted to this problem in recent years (Andrews, 1980; Andrews and Nelson, 1989; Kellerhals and Church, 1989; Deitrich et al., 1993; Church, 1995) and more work is needed. In general, flows that mobilize substrata of median particle diameter will build bars, cut overflow channels and dig pools. Determination of peak flows is complicated by dense, often senescent, thickets of riparian vegetation on the floodplains of regulated rivers. Repeated scouring flows will most likely restore riparian successional vitality. Annual temperature patterns similar to pre-regulation conditions, which will directly mediate restoration of biota, can often be attained by depth selective withdrawal structures on the dams (Gore, 1985).

Of course, restoration of overbank flows may be problematic in many rivers where humans have colonized the floodplains. In these cases, revetments have often been extensively built to restrain flood flows. Reregulation to produce overbank flows may not be practical. However, floods of record will most likely result in overbank flow even in intensely regulated rivers, because natural storage on floodplains throughout the continuum has been drastically diminished. Revetments tend to act as dams during very large floods on 


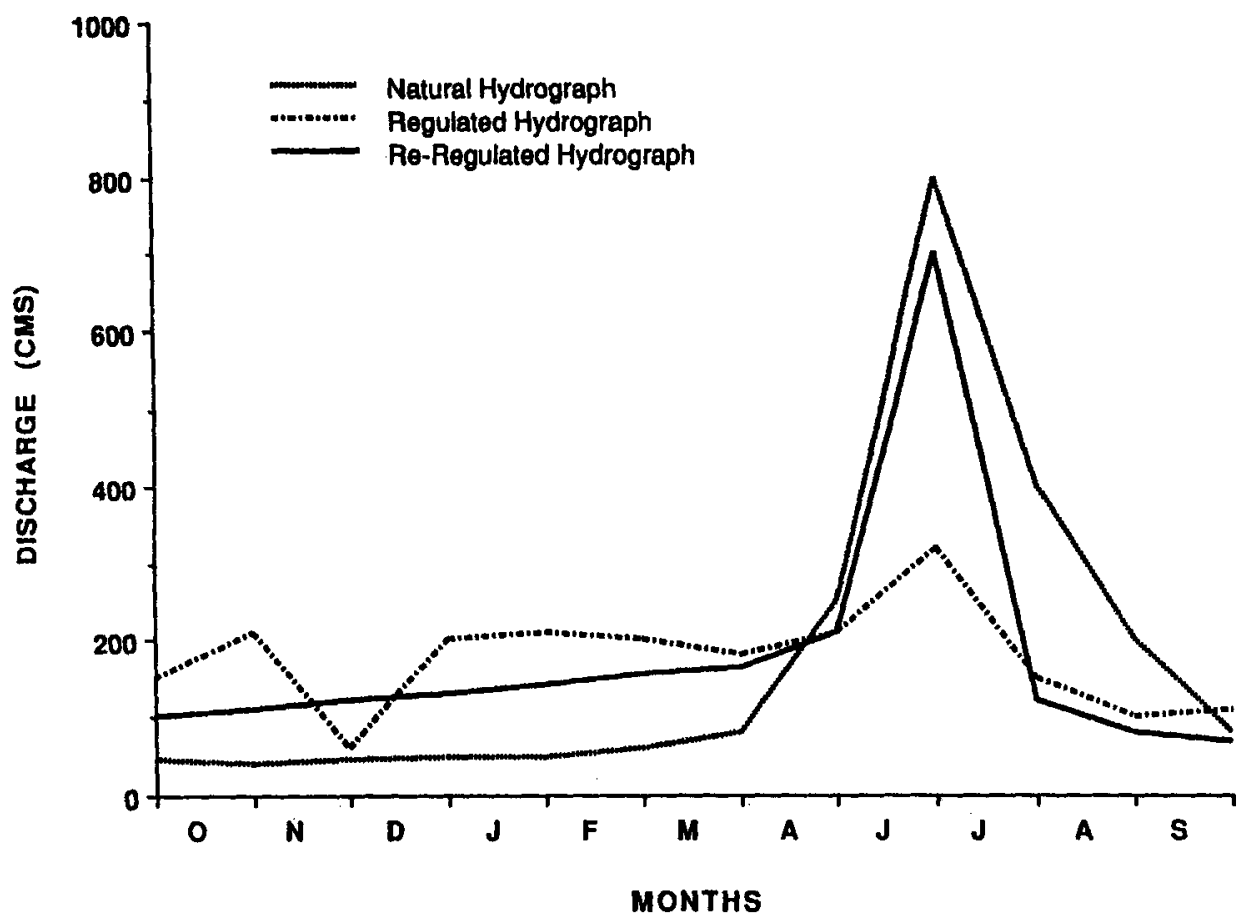

Figure 6. Simulated annual discharge $\left(\mathrm{m}^{3} / \mathrm{s} \times 10\right.$, mean monthly flow) patterns in the Hanford Reach of the Columbia River, USA. The same volume of water passed through the reach in each of the three scenarios (derived from US Geological Survey data, Reston, Virginia, USA)

aggraded rivers and extensive scouring of floodplain surfaces occurs if revetments are breached. Recent floods (1993-1995) of such magnitude in large rivers of western Europe, southern Scandinavia, Bangladesh and the USA provided evidence of the value of vacating floodplains to reduce the human costs and exploit natural flood pulsing (Sparks, 1995).

The strong inference for management is to protect uncolonized floodplains by re-establishing periodic overbank flooding, allowing the river to rebuild habitats. Elsewhere, incentives will be needed to get people to vacate floodplains so that revetments can be removed allowing reconnection of channels and floodplains. If that is not practical or desired by stakeholders, development of strategies for reconnecting severed lowland floodplain wetlands and backwaters by use of lateral flow control structures may be useful (Gore, 1985; Gore and Shields, 1995). In situations where alluvial areas have been inundated, it may be possible to lower permanently the full pool level of the reservoir, allowing riverine cut and fill alluviation to reconfigure and restore drowned floodplains. As in dam removal, this scenario requires careful evaluation because sediment transport dynamics may be different from those that occurred prior to regulation.

Whereas peak flows are needed to restore natural habitat heterogeneity, usually stabilization of baseflow fluctuations will also be needed to revitalize the varial zone of the channel (Figure 1). Establishment of sustained baseflows restores biodiversity and bioproduction in shallow water habitats, which are critically important to benthic insects that must emerge from the shorelines of rivers, and small fishes that must reside on or near substratum in low velocity habitats (Perry and Perry, 1986; Weisberg et al., 1990; Travnichek et al., 1995).

Reregulation in most rivers can be accomplished without substantially compromising storage or hydropower (Figure 6). Peak flows are built from storage and runoff and released in concert with natural runoff timing in the catchment (Figure 4). In wet years, peaks can be reregulated to approach floods of record, depending on the release capability of the dam. Very high flows are not needed every year to maintain instream and floodplain habitats nor is the historical duration of floods likely to be required because 
most of the sediment is moved on the rising limb of the hydrograph. In years of average catchment water yield, a modest peak flow can be generated, while also elevating baseflow to accomplish the purposes for which the dams were built. In dry years, peak flows can be minimal or non-existent (Figure 4). The strategy is simply to lower the baseflow a little to build peaks in relation to catchment runoff. In all years it is essential to prevent massive dewatering of the varial zone during baseflow periods; explicitly, this means that daily changes in flow (ramping rates) should not exceed the range of variation that occurred before regulation (Figure 4).

Operators of hydroelectric dams may object to reregulation recommendations as depicted in Figure 6, because of the potential constraints on generation of peak power and concern often exists that the legal requirements for electrical load control cannot be met. On the contrary, load control can be performed without ramping flow beyond the range of variation observed in pre-regulation periods (Jourdonnais and Hauer, 1993). Loss of peaking is problematic. However, most large dams are part of large electrical marketing grids and alternatives to hydropower peaking exist today that were not available a decade ago. For example, modern fuel turbines are very effective peaking units, natural gas reserves are large world-wide and local utilities are finding gas-powered turbines to be preferred alternatives to the purchase of regional hydropower. The need for hydropower peaking may wane in the next decade, particularly if the cost of, and public desire for, downstream environmental mitigation increases.

\section{Maximize passage efficiency to allow recovery of metapopulations}

Maintenance of instream and floodplain habitats by restoration of peak flows and revitalization of shallow and slack water habitats by stabilization of baseflows will increase ecological connectivitiy along all three spatial dimensions. However, in the absence of dam and reservoir removal, optimization of dam and reservoir passage efficiency for biota is required to reconnect the longitudinal dimension (Figure 2). Mechanisms for significantly reducing mortality of juvenile and adult fish as they pass hydroelectric dams include flowing ladders, travelling screens, surface-release attractors and other bypass devices (Gore, 1985). The main point is that dams with no, or very inefficient, bypass systems maintain the discontinuum and isolate populations, thereby limiting the gene flow that may be needed to restore and maintain metapopulations. On the other hand, the presence of impassable dams in some cases has prevented immigration of non-native species into native food-webs and effectively isolated viable native populations (Stanford and Hauer, 1992).

In many large, regulated rivers, viable populations of native species remain in segments isolated by dams. Restoration of flow and temperature seasonality and reconnection of these refugia may restore critically important core areas, revitalize metapopulation structure and rapidly lead to recovery of genetically and numerically depressed populations (Sedell et al., 1990; DeVore et al., 1995). Indeed, a primary strategy of large river restoration should be to identify, stabilize, restore and reconnect river segments to core areas containing native food-webs. The expectation is that native species will recolonize restored habitat from the core area (Lichatowich et al., 1995; Frissell and Bayles, 1996). The process can be mediated by artificial supplementation (replanting) of the vestigial stock if the native gene pool is properly cultured. However, this strategy is fraught with risk owing to the complexity of locally adapted stocks (Lichatowich et al., 1995). Perhaps a better strategy is to reconnect the beads and allow the biota to adapt. How long this will take is a key question; biology itself can be limiting. Time frames for recovery will probably vary from years to decades depending on the degree of habitat degradation, the strength of normative conditions and the species involved. We note that biota in the rivers devastated by the eruption of Mount St. Helens, Washington, USA, in 1980 returned much sooner than expected (Anderson and Wisseman, 1987; Lamberti et al., 1992; Leider, 1989) and chinook salmon in New Zealand rivers developed locally adapted life histories within 50 years after initial introduction (Quinn and Unwin, 1993).

\section{Minimize planting of cultured stocks}

Contemporary fisheries management is based on a belief system that embraces the concept that loss of bioproduction and biodiversity from stream regulation can be mitigated by construction and operation of artificial culture systems. In other words, the belief is that habitat loss caused by stream regulation can be replaced, if not enhanced, by artificial propagation. Perhaps no greater myth exists in ecology. While 
economically important, non-native salmonid and other fisheries have been established from cultured stocks in river segments world-wide, in almost every case this practice has failed miserably to meet its objective of replacing lost fisheries (Lichatowich, in press). Stocking of native and non-native fish has irresponsibly compromised native food-webs around the world and is rightfully called the Frankenstein Effect (Moyle et al., 1986). A large body of literature debates this problem; the bottom line is that culture operations should be avoided unless native biota are clearly headed for extinction as a consequence of habitat loss (Minckley and Deacon, 1991; Hilborn, 1992). Even then, cultured stocks cannot be expected to re-establish if they are simply released back into the same degraded habitats. Ecological bottlenecks that compromised endangered species in the first place have to be rectified, and the only way to do that in large river systems is to restore habitat in a continuum context.

\section{Be wary of management actions that attempt to control riverine food webs}

Perhaps the greatest uncertainty in reregulating river systems to restore hot spot connectivity (Figure 2) is the unexpected consequence of the inexorable proliferation of non-native biota. Wendell Minckley and James Deacon, the sages of fish ecology in the species-rich American Southwest often rightly noted that locally adapted fish of the desert are clearly able to deal with extreme environmental variation, but natives are quickly depressed or driven to extinction by food-web change associated with invasions of non-native species (e.g. Minckley and Douglas, 1991). However, restoration of natural flow and temperature dynamics compromises the ability of non-native species to sustain viable populations and promotes native species (Li et al., 1987; Meffe and Minckley, 1987; Bain et al., 1988). Even with restoration of the full range of natural flow variation, interactions with non-native plants and animals will most likely continue to be a problem for native biodiversity management and conservation.

One alternative is to control non-native populations by aggressive harvest. However, it is very difficult to do this without also affecting natives, and prediction of the influence of the food-web structure is tenuous at best. Moreover, in some cases one or a few native species have become very abundant in regulated rivers along with non-natives. For example, native squawfish (Ptychocheilus oregonensis) in the Columbia River, USA, are thought to be a major source of predation mortality for juvenile salmon, which exist in very depressed populations (Poe et al., 1991; Rieman et al., 1991) and a very aggressive control programme has been initiated by paying fishermen a bounty for each squawfish caught. However, food-web structure in the lower Columbia River is poorly known, a wide variety of non-native predators are present and predicting food-web responses as well as influences on salmon mortality is tenuous. A congener ( $P$. lucius) in the Colorado River is listed as endangered and a very expensive recovery program has been initiated. For many people these strategies seem at crosspurposes, even though the ecology of the two species is very different.

In general, the effectiveness of predator control programmes is minimal or poorly demonstrated even though it is a very popular management strategy. We agree with Goodrich and Buskirk (1995) that population control of abundant native vertebrates should be a strategy of last resort for conservation of rare natives. Columbia River salmon evolved with squawfish predation and restoration of proper habitats for salmon smolts clearly should reduce smolt mortality. However, constraining proliferation of non-native plants and animals is an obvious need for conservation of native biodiversity.

Again, the preferred approach may be to implement reregulation to restore lost habitat and allow the food-web to adjust as it will. The available body of information suggests that natives will fare better than non-natives. Clearly, it is advisable to document and monitor food-web dynamics carefully from a community ecology perspective.

\section{Use adaptive ecosystem management}

Any strategy to remediate the effects of large river regulation will require an adaptive approach. Scientists can be relied upon to document ecological problems by research and synthesis of empirical information on cause and effect, but the solution of problems must involve knowledge of human perceptions and desires, which are often different from that inferred by the strict interpretation of the science (Ludwig et al., 1993). In most cases, inefficient information transfer between science, management, policy makers (government) and the general public hinders the attainment of common ground. 
Adaptive ecosystem management (Lee and Lawrence, 1986) is a useful process for solving the catchmentscale problems discussed herein. We agree with Stanford and Poole (1996) who advocate an iterative, stepwise approach that involves synthesis of available information in an ecosystem context to define the problem, public participation in goal setting (e.g. protection and restoration of native biodiversity), research and peer review to define science-based management actions (e.g., reregulation), effective monitoring and evaluation of management actions and adaptive revision of actions based on new information from scientific research.

\section{CONCLUSIONS}

Reregulation of large river systems from headwaters to mouth for the purpose of restoring and reconnecting hot spots of native biodiversity and bioproduction has not been accomplished anywhere to date. Our protocol should be viewed as an hypothesis in need of an experimental catchment. Many candidate rivers exist. We recognize that this analysis has not adequately considered the economic and social ramifications of our protocol. A fundamental problem is that the metrics for linking natural and cultural elements of ecosystems remain elusive. Perhaps that shortcoming can be solved through multidisciplinary examination of large river ecosystems using adaptive management. However, the reality is that sustainability of natural attributes of large river ecosystems is vastly compromised by regulation. Site-specific mitigation activities that ignore the biophysical continuum hold little promise and can be very costly when continued without evaluation year after year. The logical alternative is to try restoring biophysical connectivity of an entire regulated river ecosystem using the protocol proposed herein and adapted to the specifics of the selected river. Restoration of some large portion of lost capacity to sustain native biodiversity and bioproduction seems possible, especially in large rivers with a substantial portion of the continuum remaining in a free-flowing state. The cost may be less than expected because the river can do the most of the work.

\section{ACKNOWLEDGEMENTS}

Financial support for this paper was provided in part by the Northwest Power Planning Council, Portland, Oregon, USA, and National Science Foundation grant number OSR-955450 but no endorsement of the paper was made or implied. We thank Geoffrey C. Poole for help with graphics and three anonymous reviewers for their constructive comments. Charles C. Coutant is with the Oak Ridge National Laboratory, which is managed by Lockheed Martin Energy Research Corporation, under contract DE-AC0596OR22464 with the U.S. Department of Energy.

\section{REFERENCES}

Amoros, C., A. Roux, L., Reygrobellet, J. L., Bravard, J. P. and Pautou, G. 1987. 'A method for applied ecological studies of fluvial hydrosystems', Regul. Riv., 1, 17-36.

Anderson, N. H. and Wisseman, R. W. 1987. 'Recovery of the Trichoptera fauna near Mt. St. Helens five years after the 1980 eruption', in Bournaud, M. and Tachet, H. (Eds), Proceedings of the 5 th International Society on Trichoptera, Junk, Dordrecht. The Netherlands. pp. 367-373.

Andrewartha, H. G. and Birch, L. C. 1954. The Distribution and Abundance of Animals. University of Chicago Press, Chicago. 281 pp. Andrews, E. D. 1980. 'Effective and bankfull discharges in the Yampa River Basin, Colorado and Wyoming', J. Hydrol., 43, 311-330.

Andrews, E. D. and Nelson, J. M. 1989. 'Topographic response of a bar in the Green River, Utah to variation in discharge', in Ikeda, S. and Parker, G. (Eds), River Meandering. American Geophysical Union. pp. 463-485.

Angermeier, P. L. and Karr, J. R. 994. 'Biological integrity versus biological diversity as policy directives', BioScience, 44(10), 690-697.

Bachman, R. A. 1983. 'Foraging behavior of free-ranging wild brown trout (Salmo trutta) in a stream', Trans. Am. Fish. Soc., 113, 1-32.

Bain, M. B., Finn, J. T. and Booke, H. E. 1988. 'Stream-flow regulation and fish community structure', Ecology 69, $382-392$.

Baxter, R. M. 1977. 'Environmental effects of dams and impoundments', Ann. Rev. Ecol. System., 8, 255-283.

Benke, A. C., Hall, C. A. S., Hawkins, C. P., Lowe-McConnell, R. H., Stanford, J. A., Subetkropp K. and Ward, J. V. 1988. 'Bioenergetic considerations in the analyses of stream ecosystems', J. North Am. Benthol. Soc. ,7(4), 480-502.

Best, J. L. and Bristow, C. S. (Ed.), 1993. Braided Rivers. Geological Society Special Publications. The Geological Society, London. 419 pp.

Blikie, P. and Brookfield, H. 1987. Land Degradation and Society. Methuen, New York. 453 pp.

Blinn, D. W., Shannon, J. P., Stevens L. E. and Carder, J. P. 1995. 'Consequences of fluctuating discharge for lotic communities', $J$. North Am. Benthol. Soc., 14, 233-248. 
Brett, J. R. 1971. 'Energetic responses of salmon to temperature. A study of some thermal relations in the physiology and freshwater ecology of sockeye salmon (Oncorhynchus nerka)', Am. Zool., 11, 99-113.

Brown, J.H. and Kodric-Brown, A. 1977. 'Turnover rates in insular biogeography: effects of immigration on extinction', Ecology, 58, 445-449.

Calow, P. and Petts, G. E. (Eds), 1992. The Rivers Handbook, Volume 1, Hydrological and Ecological Principles. Blackwell Scientific, Oxford.

Church, M. 1995. 'Geomorphic response to river flow regulation: case studies and time-scales', Reg. Riv., 11(1), 3-22.

Connell, J. H. 1978. Diversity in tropical rain forests and coral reefs', Science, 199, 1302-1310.

Connor, J. E. 1993. Hydrology, Hydraulics and Geomorphology of the Bonneville Flood, US Geological Survey Special Paper 274. US Govt. Printing Office, Washington.

Copp, G. H. 1989. 'The habitat diversity and fish reproductive function of floodplain ecosystems', Environ. Biol. Fishes, 26, 1-27.

Cummins, K. W., Minshall, G. W., Sedell, J. R., Cushing, C. E. and Petersen, R. C. 1984. 'Stream ecosystem theory', Verh. Internat. Verein. Theor. Angew. Limnol., 22, 1818-1827.

Cummins, K. W., Wilzbach, M. A., Gates, D. M., Perry, J. B. and Taliaferro, W. B. 1989. 'Shredders and riparian vegetation. Leaf litter that falls into streams influences communities of stream invertebrates', BioScience, 39(1), 24-30.

Cushman, R. M. 1985. 'Review of ecological effects of rapidly varying flows downstream of hydroelectric facilities', North Am. J. Fisheries Man., 5, 330-339.

Dahm, C. N., Cummins, K. W., Valett, H. M. and Coleman, R. L. 1995. 'An ecosystem view of the restoration of the Kissimmee River'. Restoration Ecol., 3(3), 225-238.

Davies, B. R. and Walker, K. F. (Ed.), 1986. The Ecology of River Systems. Dr. W. Junk, Dordrecht, The Netherlands. 793 pp.

Decamps, H. and Tabacchi, E. 1994. 'Species richness in vegetation along river margins', in Giller, P. S., Hildrew, A. G. and Raffaelli, D. G. (Eds), Aquatic Ecology: Scale, Pattern and Process. Blackwell Scientific Publications, London.

DeVore, J. D., James, B. W., Tracy, C. A. and Hale, D. A. 1995. 'Dynamics and potential production of white sturgeon in the unimpounded Lower Columbia River', Trans. Am. Fish. Soc., 124(6), 845-856.

Dolan, R., Howard, A. and Trimble, D. 1978. 'Structural control of the rapids and pools of the Colorado River in the Grand Canyon', Science, 202, 629-631.

Doppelt, B., Scurlock, M., Frissell, C. and Karr, J. 1993. Entering the Watershed. Island Press, Washington, D.C. 462 pp.

Dynesius, M. and Nilsson, C. 1994. 'Fragmentation and flow regulation of river systems in the northern third of the world', Science, 266, $753-762$.

Ebersole, J.L., Liss, W.J. and Frissell, C.A. In press. 'Restoration of stream habitats in managed landscapes in the western USA: restoration as re-expression of habitat capacity', Environ. Manage.

Frissell, C. A. 1993. 'Topology of extinction and endangerment of native fishes in the Pacific northwest and California (U.S.A.)', Conservation Biol., 7(2), 342-354.

Frissell, C. A. and Bayles, D. 1996. Ecosystem management and the conservation of aquatic biodiversity and ecological integrity', Wat. Res. Bull., 32, 229-240.

Frissell, C. A. and Nawa R. K. 1992. 'Incidence and causes of physical failure of artificial habitat structures in streams of western Oregon and Washington', North Am. J. Fish. Manage., 12, 182-197.

Frissell, C. A., Liss W. J. and Bayles, D. 1993. 'An integrated, biophysical strategy for ecological restoration of large watersheds', in Spangenborg, N. E. and Potts, D. E. (Ed.), Proceedings of the Symposium on Changing Roles in Water Resources Management and Policy. American Water Resources Association, Bethesda. pp. 449-456.

Frissell, C. A., Liss, W. J., Gresswell, R. E., Nawa, R. K. and Ebersole, J. L. In press. 'A resource in crisis: changing the measure of salmon management', in Stouder, D. J., Bisson, P. A. and Naiman, R. J. (Eds). Pacific Salmon and their Ecosystems: Status and Future Options. Chapman \& Hall, New York.

Gibert, J., Dole-Olivier, M. J,, Marmonier, P. and Vervier, P. 1990. 'Surface water-groundwater ecotones', in Naiman, R. J. and Decamps, H. (Eds), Ecology and Management of Aquatic-Terrestrial Ecotones. Partenon Publ., London. pp. 199-255.

Gislason, G. M. 1985. 'The life cycle and production of Simulium vittatum Zett. in the River Laxa, North-East Iceland', North Am. $J$. Fish. Manage., 22, 3281-3287.

Goodrich, J. M. and Buskirk, S. W. 1995. 'Control of abundant native vertebrates for conservation of endangered species', Conservation Biol., 9(6), 1357-1364.

Gore, J. A., (Ed.), 1985. The Restoration of Rivers and Streams: Theories and Experience. Butterworth Publishers, Stoneham. 280 pp.

Gore, J. A. and Shields, J. F. D. 1995. 'Can large rivers be restored?', BioScience, 45(3), 142-152.

Gotelli, N.J. 1991. 'Metapopulation models: the rescue effect, the propagule rain, and the core-satellite hypothesis', American Naturalist, $138,768-776$.

Gregory, S. V., Swanson, F. J., McKee, W. A. and Cummins, K. W. 1991. 'An ecosystem perspective of riparian zones', BioScience, $41(8), 540-551$

Hall, C. A. S. 1986. 'The changing intellectual climate of fisheries management', Environ. Manage., 10(3), 331-334.

Hall, C. A. S. 1988a. 'An assessment of several of the historically most influential theoretical models used in ecology and of the data provided in their support', Ecol. Model., 43, 5-31.

Hall, C. A. S. 1988b. 'What constitutes a good model and by whose criteria?', Ecol. Model., 43, 125-127.

Hall, C. A. S., Stanford, J. A. and Hauer, F. R. 1992. 'The distribution and abundance of organisms as a consequence of energy balances along multiple environmental gradients', Oikos, 65, 377-390.

Hanski, I. 1991. 'Single species metapopulation dynamics: concepts, models and observations', Biol. J. Linnean Soc., 42, 17-38.

Hanski, I. and Gilpin, M. 1991. 'Metapopulation dynamics: brief history and conceptual domain', Biol. J. Linnean Soc., 42, 3-16.

Harmon, J. R. and Park, D. L. 1980. 'Evaluation of a bypass sytem for juvenile salmonids at Little Goose Dam', Marine Fish. Rev., June, $25-28$.

Harrison, S. 1991. 'Local extinction in a metapopulation context: an empirical evaluation', Biol. J. Linnean Soc., 42, 73-88.

Harrison, S. 1994. 'Metapopulations and conservation', in Edwards, P. J., May, R.M. and Webb, N.R. (Eds), Large-scale Ecology and Conservation Biology. Blackwell Scientific Publications, Oxford. $375 \mathrm{pp}$ 
Harrison, S. and Quinn, J.F. 1989. 'Correlated environments and the persistence of metapopulations'. Oikos, 56, 293-298.

Hauer, F. R., Stanford, J. A. and Ward, J. V. 1989. 'Serial discontinuities in a Rocky Mountain river. II. Distribution and abundance of Trichoptera', Regul. Riv. Res., 3, 177-182.

Hilborn, R. 1992. 'Hatcheries and the future of salmon in the Northwest', Fisheries, 17(1), 5.

Hunter, C. J. 1991. Better Trout Habitat: A Guide to Stream Restoration and Management. Island Press, Washington, D.C. 320 pp.

Huntington, C., Nehlsen, W. and Bowers, J. 1996. 'A survey of healthy native stocks of anadromous salmonids in the Pacific Northwest and California'. Fisheries, 21, 6-14.

Huston, M. 1979. 'A general hypothesis of diversity', American Naturalist, 113, 81-101.

Huston, M. A. 1994. Biological Diversity: The Coexistence of Species on Changing Landscapes. Cambridge University Press, Cambridge. $681 \mathrm{pp}$.

Hynes, H. B. N. 1966. The Biology of Polluted Waters. Liverpool University Press, Liverpool. 202 pp.

Hynes, H. B. N. 1975. 'The stream and its valley', Verh. Intern. Verein. Theor. Angew. Limnol., 19, 1-15.

Illies, J. 1956. 'Seeausfluss-Biozönosen lappländischer Waldbäche', Ent. Tidskr., 77, 138-153.

Illies, J. and Botosaneanu, L. 1963. 'Problemes et methodes de la classification et de la zonation ecologique des eaux courantes, considerees surtout du point de vue faunistique', Mitteil. Internat. Verein. Theor. Angew. Limnol., 12, 1-57.

Johnson, W. C. 1994.' Woodland expansion in the Platte River, Nebraska: patterns and causes', Ecol. Monographs, 64(1), 45-84.

Jourdonnais, J. H. and F. R. Hauer. 1993. 'Electrical frequency control and its effects on flow and river ecology in the lower Flathead River, Montana', Rivers, 4(2), 132-145.

Junk, W. J. and Piedade M. T. F. 1994. 'Species diversity and distribution of herbaceous plants in the floodplain of the middle Amazon', Verh. Internat. Verein. Theor. Angew. Limnol., 25, 1862-1865.

Junk, W. J., Bayley, P. B. and Sparks, R. E. 1989. 'The flood pulse concept in river-floodplain systems' in Dodge, D. P. (Ed.), Proc. Int. Large River Symposuim, Can. Spec. Publ. Fish. Aquat. Sci., 106, 110-127.

Heiler, G., Hein, T., Schiemer, F. and Bornette, G. 1995. 'Hydrological connectivity and flood pulses as the central aspects for the integrity of a river-floodplain system'. Regul. Riv, 11(3/4), 351-361.

Kellerhals, R. and Church, M. 1989. 'The morphology of large rivers: characterization and management', Can. Spec. Publ. Fish. Aquat. Sci., 106, 31-48.

Kondolf, G. M. and Larson, M. 1995. 'Historical channel analysis and its application to riparian and aquatic habitat restoration', Aqua. Conserv. Mar. Freshwater Ecosystems, 5(2), $109-126$.

Krueger, C. C. and Waters, T. F. 1983. 'Annual production of macroinvertebrates in three streams of different water quality', Ecology, $64,840-850$.

Lamberti, G. A., Gregory, S. V., Hawkins, C. P., Wildman, R. C., Ashkenas, L. R. and Denicola, D. M. 1992. 'Plant herbivore interactions in streams near Mount St Helens', Freshwater Biol., 27, 237-247.

Lee, K. N. and Lawrence J. 1986. 'Adaptive management: learning from the Columbia River Basin fish and wildlife program', Environ. Law, 16, 431-460.

Leider, S. A. 1989. 'Increased straying by adult steelhead trout, Salmo gairdneri, following the 1980 eruption of Mount St. Helens', Environ. Biol. Fishes, 24, 219-229.

Leopold, L. B., Wolman, M. G. and Miller, J. P. 1964. Fluvial Processes in Geomorphology. W. H. Freeman and Co., San Francisco. $522 \mathrm{pp}$.

Li, H. W., Schreck, C. B., Bond, C. E. and Rexstad, E. 1987. 'Factors influencing changes in fish assemblages of Pacific Northwest streams', in Matthews, W. J. and Heins, D. C. (Eds), Community and Evolutionary Ecology of North American Stream Fishes. University of Oklahoma Press, Norman. pp. 193-202.

Li, H. Currens, W., K., Bottom, D., Clarke, S., Dambacher, J., Frissell, C., Harris, P., Hughes, R. M., McCullough, D., McGie, A., Moore, K. and Thiel, S. in press. 'Safe havens: refuges and evolutionarily significant units', Am. Fish. Soc. Symp., 17.

Lichatowich, J. in press. 'Evaluating the performance of salmon management institutions: the importance of performance measures, temporal scales and production cycles', in Stouder, D. J., Bisson, P. A. and R. J. Naiman (Eds), Pacific Salmon and Their Ecosystems. Chapman \& Hall, New York.

Lichatowich, J. A. and Mobrand, L. E. 1995. Analysis of Chinook salmon in Columbia River from an Ecosystem Perspective. US Department of Energy, Banneville Power Administration, Portland, Oregon. 102 pp.

Lichatowich, J., Mobrand, L., Lestelle, L. and Vogel, T. 1995. 'An approach to the diagnosis and treatment of depleted Pacific salmon populations in Pacific Northwest watersheds', Fisheries, 20(1), 10-18.

Ligon, F. K., Dietrich, W. E. and Trush, W. J. 1995. 'Downstream ecological effects of dam', BioScience, 45(3), $183-192$.

Lillehammer, A. and Saltveit, S. J. (Eds), 1984. Regulated Rivers. Oslo University Press, Oslo. 540 pp.

Lowe-McConnell, R. H. 1987. Ecological Studies in Tropical Fish Communities. Cambridge University Press, Cambridge

Lubchenco, J., Olson, A. M., Brubaker, L. B., Carpenter, S. R., Holland, M. M., Hubbell, S. P., Levin, S. A., MacMahon, J. A., Matson, P. A., Melillo, J. M., Mooney, H. A., Peterson, C. H., Pulliam, H. R., Real, L. A., Regal, P. J. and Risser, P. G. 1991. 'The sustainable biosphere initiative: An ecological research agenda', Ecology, 72(2), 371-412.

Ludwig, D., Hillborn R. and Walters, C. 1993. 'Uncertainty, resource exploitation and conservation: Lessons from history', Science, 260, $17-36$.

Mangin, A. 1994. 'Karst hydrogeology', in Gibert, J., Danielopol, D. L. and Stanford, J. A. (Eds), Groundwater Ecology. Academic Press, Inc., San Diego, California. pp. 43-68.

McAuliffe, J. R. 1983. 'Competition, colonization patterns and disturbance in stream benthic communities', in Barnes, J. R. and Minshall, G. W. (Eds.), Stream Ecology: Application and Testing of General Ecological Theory, Plenum Press, New York, $399 \mathrm{pp}$.

McAuliffe, J. R. 1984. 'Competition for space, disturbance, and the structure of a benthic stream community'. Ecology, 65, 894-908.

Meffe, G. K. and Minckley W. L. 1987. 'Persistence and stability of fish and invertebrate assemblages in a repeatedly disturbed Sonoran Desert stream', Am. Midland Naturalist, 117, 177-191.

Milner, A. M. and Bailey, R. G. 1989. 'Salmonid colonization of new streams in Glacier Bay National Park, Alaska', Aquaculture Fish. Manage., 20, 179-192. 
Minckley, W. L. and Deacon, J. E. (Eds). 1991. Battle Against Extinction: Native Fish Management in the American West. University of Arizona Press, Tucson. 535 pp.

Minckley, W. L. and Douglas, M. E. 1991. 'Discovery and extinction of western fishes: a blink of the eye in geologic time', in Minckley, W. L. and Deacon, J. E. (Eds), Battle Against Extinction: Native Fish Management in the American West. University of Arizona Press, Tucson. pp. 7-17.

Minshall, G. W. 1978. 'Autotrophy in stream ecosystems', BioScience, 28(12), 767-771.

Minshall, G. W., Petersen, R. C., Cummins, K. W., Bott, T. L., Sedell, J. R., Cushing, C. E. and Vannote, R. L. 1983. 'Interbiome comparison of stream ecosystem dynamics' Ecol. Monographs, , 53, 1-25.

Mooney, H. A. and Drake, J. A. (Eds). 1986. Ecology of Biological Invasions of North America and Hawaii. Springer-Verlag, New York.

Moyle, P. B. and Leidy, R. A. 1992. 'Loss of biodiversity in aquatic ecosystems: evidence from fish faunas', in Fielder, P. L. and Jain, S. K. (Ed.), Conservation Biology: The Theory and Practice of Nature, Conservation, Preservation and Management. Chapman and Hall, New York. pp. 128-169.

Moyle, P. B., Li H. W. and Barton, B. A. 1986. 'The Frankenstein effect: Impact of introduced fishes on native fishes in North America', in Stroud, R. H. (Ed.), Fish Culture in Fisheries Manag.. Am. Fish. Soc., Maryland. pp. 415-426.

Munn, M. and Brusven, M. A. 1991. 'Benthic macroinvertebrate communities in nonregulated and regulated waters of the Clearwater River, Idaho', Regul. Riv., 6, 1-11.

Naiman, R. J., Melillo, J. M., Lock, M. A., Ford, T. E. and Reice, S. R. 1987. 'Longitudinal patterns of ecosystem processes and community structure in a subarctic river continuum', Ecology, 68, 1139-1156.

Naiman, R. J., Decamps, H., Pastor, J. and Johnston, C. A. 1988. 'The potential importance of boundaries to fluvial ecosystems', J. North Am. Benthol. Soc., 7(4), 289-306.

Naiman, R. J., Magnuson, J. J., McKnight, D. M. and Stanford, J. A. (Eds). 1995a. Freshwater Imperative: A Research Agenda, Ist edn., Island Press, Washington, D.C. $165 \mathrm{pp}$.

Naiman, R. J., Magnuson, J. J., McKnight, D. M., Stanford, J. A. and Karr, J. R. 1995b. 'Freshwater ecosystems and their management: a national initiative', Science, 270(5236), 584-585

National Research Council, 1995. Upstream: Salmon and Society in the Pacific Northwest. National Academy of Sciences, Washington, D.C. 388 pp.

Nehlsen, W., Williams, J. E. and Lichatowich, J. A. 1991. 'Pacific salmon at the crossroads: stocks at risk from California, Oregon, Idaho, and Washington', Fisheries, 16(2), 4-21.

Newbold, J. D., Elwood, J. W., O'Neill, R. V. and Van Winkle, W. 1981. 'Measuring nutrient spiralling in streams', Can. J. Fish. Aquat. Sci., 38(7), 860-863.

Newbold, J. D., O'Neill, R. V., Elwood, J. W. and Van Winkle, W. 1982. 'Nutrient spiralling in streams: implications for nutrient limitation and invertebrate activity', American Naturalist, 120(5), 628-652.

Noss, R. F. and Cooperrider, A. Y. 1994. Saving Nature's Legacy: Protecting and Restoring Biodiversity. Island Press, Washington, D.C.

Perry, S. A. and Perry, W. B. 1986. 'Effects of experimental flow regulation on invertebrate drift and stranding in the Flathead and Kootenai Rivers, Montana, USA', Hydrobiologia, 134, 171-182.

Perry, S. A. and Sheldon, A. L. 1986. 'Effects of exported seston on aquatic insect faunal similarity and species richness in lake outlet streams in Montana, USA', Hydrobiologia, 137, 65-77.

Petts, G. E. and Wood, R. (Eds). 1988. 'River regulation in the United Kingdom', Regul. Riv., 2(3).

Petts, G. E., Moller, H. and Roux, A. L. (Ed.). 1989. Historical Change of Large Alluvial Rivers: Western Europe. John Wiley \& Sons, Chichester. 355 pp.

Pflieger, W. L. and Grace, T. B. 1987. 'Changes in the fish fauna of the Lower Missouri River, 1940-1983', in Matthews, W. J. and Heins, D. C. (Eds), Community and Evolutionary Ecology of North American Stream Fishes. University of Oklahoma Press, Norman. pp. $166-177$.

Pimm, S. L. 1991. The Balance of Nature? Ecological Issues in the Conservation of Species and Communities. University of Chicago Press, Chicago. 447 pp.

Poe, T. P., Hansel, H. C., Vigg, S., Palmer, D. E. and Prendergast, L. A. 1991. 'Feeding of predaceous fishes on out-migrating salmonids in John Day Reservoir, Columbia River', Trans. Am. Fish. Soc., 120(4), 405-420.

Poff, N. L. and Allan, J. D. 1995. 'Functional organization of stream fish assemblages in relation to hydrological variability', Ecology, 76(2), 606-627.

Poff, N. L. and Ward, J. V. 1990. 'Physical habitat template of lotic systems: recovery in the context of historical pattern of spatiotemporal heterogeneity', Environ. Manage., 14, 629-645.

Power, M. E., Sun, A., Parker, G., Dietrich, W. E. and Wootton, J. T. 1995. 'Hydraulic food-chain models', BioScience, 45(3), $159-167$.

Quinn, T.P. and Unwin, M. J. 1993. 'Variation in life history patterns among New Zealand chinook salmon (Oncorhynchus tshawytscha) populations', Can. J. Fish. Aquat. Sci., 50, 1414-1421.

Regier, H. A., Welcomme, R. L., Stedman, R. J. and Henderson, H. F. 1989. 'Rehabilitation of degraded river ecosystems', in Proceedings, of the International Large River Symposium. Can. Spec. Publ. Fish. Aquat. Sci., pp. 86-89.

Reice, S. R. 1994. 'Nonequilibrium determinants of biological community structure', American Scientist, 82(5), 424-435.

Reisenbichler, R. R., McIntyre, J. D., Solazzi, M. F. and Landino, S. W. 1992. 'Genetic variation in steelhead of Oregon and Northern California', Trans. Am. Fish. Soc., 121, 158-169.

Resh, V. H., Brown, A. V.,ACovich, . P., Gurtz, M. E., Li, H. W., Minshall, G. W., Reice, S. R., Sheldon, A. L., Wallace, J. B. and Wissmar, R. C. 1988. 'The role of disturbance in stream ecology', J. North Am. Benthol. Sac., 7, 433-455.

Rieman, B. E. and McIntyre, J. D. 1993. 'Demographic and habitat requirements for conservation of bull trout', Report number INT308, US Forest Service, Intermountain Research Station, Boise, Idaho, USA. 38 pp.

Rieman, B. E. and McIntyre, J. D. 1995. 'Occurrence of bull trout in naturally fragmented habitat patches of varies size', Trans. Am. Fish. Soc., 124(3), 285-296.

Rieman, B. E., Beamesderfer, R. C., Vigg, S. and Poe, T. P. 1991. 'Estimated loss of juvenile salmonids to predation by northern squawfish, walleyes, and smallmouth bass in John Day reservoir, Columbia River', Trans. Am. Fish. Soc., 120, 448-458. 
Roth, N. E., Allan, J. D. and Erickson, D. L. in press. 'Landscape influences on stream biotic integrity assessed at multiple spatial scales', Landscape Ecol.

Sabater, F., Armengol, J, and Sabater, S. 1989. 'Measuring discontinuities in the Ter River', Regul. Riv. 3, $133-142$.

Salo, J., Kalliola, R., Häkkinen, I., Mäkinen, P., Niemelä, Puhakka, M. and Coley, P. D. 1986. 'River dynamics and the diversity of Amazon lowland forest', Nature, 322, 254-258.

Schinberg, A. and Gould, K. A. 1994. Environment and Society: the Enduring Confict. St. Martins Press, New York. 324 pp.

Schlosser, I.J. and Angermeier, P.L. 1995. 'Spatial variation in de.mographic processes of lotic fishes: conceptual models, empirical evidence, and implications for conservation', Am. Fish. Soc. Symp., 17, 392-401.

Schoener, T. 1991. 'Extinction and the nature of the metapopulation', Acta Oecologia, 12, 53-75.

Schumm, S. A. and Lichty, R. W. 1956. 'Time, space and causality in geomorphology', Am. J. Sci., 263, 110-119.

Sear, D. A. 1994. 'River restoration and geomorphology', Aquat. Conserv. Marine Freshwater Ecosystems, 4, $169-177$.

Sedell, J. R., Reeves, G. H., Hauer, F. R., Stanford, J. A. and Hawkins, C. P. 1990. 'Role of refugia in recovery from disturbances: modern fragmented and disconnected river systems', Environ. Manage., 14(5) 711-724.

Shannon, J. P., Blinn, D. W. and Stevens, L. E. 1994. 'Trophic interactions and benthic animal community structure in the Colorado River, Arizona, U.S.A.', Freshwater Biol, 31, 213-220.

Shuman, J. R. 1995. 'Environmental considerations for assessing dam removal alternatives for river restoration', Regul. Riv., 11(3/4), 249-261.

Simons, D. B. 1979. 'Effects of stream regulation on channel morphology', in Ward, J. V. and Stanford, J. A. (Eds), The Ecology of Regulated Streams. Plenum Press, New York. pp. 95-111.

Southwood, T. R. E. 1977. 'Habitat, the templet for ecological strategies?', J. Animal Ecol., 46, 337-365.

Southwood, T. R. E. 1978. Ecological Methods, 2nd edn.. Chapman \& Hall, London. 524 pp.

Sparks, R. E. 1995. 'Need for ecosystem management of large rivers and their floodplains', BioScience, 45(3), $168-182$.

Sparks, R. E., Bayley, P. B., Kohler, S. L. and Osborne, L. L. 1990. 'Disturbance and recovery of large floodplain rivers', Environ. Manage., 14, 699-709.

Spencer, C. N., McClelland, B. R. and Stanford, J. A. 1991. 'Shrimp stocking, salmon collapse, and eagle displacement: cascading interactions in the food-web of a large aquatic ecosystem', BioScience, 41(1), 14-21.

Stacy, P. B. and Taper, M. 1992. 'Environmental variation and the persistence of small populations', Ecol. Appl, 2, 18-29.

Stanford, J. A. 1996. 'Landscapes and catchment basins', in Hauer, F. R. and Lamberti, G. A. (Eds), Methods in Stream Ecology. Academic Press, San Diego. pp. 3-22.

Stanford, J. A. and Hauer, F. R. 1992. 'Mitigating the impacts of stream and lake regulation in the Flathead River Catchment, Montana, USA: an ecosystem perspective', Aquat. Conserv., 2, 35-63.

Stanford, J. A. and Hauer, F. R. (Eds) 1993. 'Fifth International Symposium on Regulated Streams', Regul. Riv., 8(1/2).

Stanford, J. A., Hauer, F. R. and Ward, J. V. 1988. 'Serial discontinuity in a large river system', Verh. Internat. Verein. Theor. Angewa. Limnol, 23, 1114-1118.

Stanford, J. A. and Poole, G. C. in press. 'A protocol for ecosystem management', Ecol. Applic.

Stanford, J. A. and Ward, J. V. 1986. 'Fish of the Colorado system', in Davies, B. R. and Walker, K. F. (Eds), The Ecology of River Systems. Dr. W. Junk Publishers, Dordrecht, The Netherlands. pp. 385-402.

Stanford, J. A. and Ward, J. V. 1989. 'Serial discontinuities in a Rocky Mountain river. I. Distribution and abundance of Plecoptera', Regul. Riv, 3, 169-175.

Stanford, J. A. and Ward, J. V. 1992. 'Management of aquatic resources in large catchments: Recognizing interactions between ecosystem connectivity and environmental disturbance', in Naiman, R. J. (Ed.), Watershed Management. Springer-Verlag, New York. pp. 91-124.

Stanford, J. A. and Ward, J. V. 1993. 'An ecosystem perspective of alluvial rivers: connectivity and the hyporheic corridor', J. North Am. Benthol. Soc., 12(1), 48-60.

Statzner, B., Gore, J. A. and Resh, V. H. 1988. 'Hydraulic stream ecology: Observed patterns and potential applications', J. North Am. Benthol. Soc., 7(4), 307-360.

Stevens, L. E., Shannon, J. P. and Blinn, D. W. in press. 'Colorado River benthic ecology in Grand Canyon, Arizona: dam, tributary and geomorphic influences', Reg. Riv.

Taylor, E.B. 1991. 'A review of local adaptation in Salmonidae, with particular reference to Pacific and Atlantic salmon', Aquaculture, 98, 185-207.

Toth, L. A., Obeysekera, J. T. B., Perkin, W. A. and Loftin, M. K. 1993. 'Flow regulation and restoration of Florida's Kissimmee River', Reg. Riv., 8(1/2), 155-166.

Townsend, C. R. 1989. 'The patch dynamics concept of stream community ecology', J. North Am. Benthol. Soc., 8, 36-50.

Travnichek, V. H., Bain, M. B. and Maceina, M. J. 1995. 'Recovery of a warmwater fish assemblage after the initiation of a minimumflow release downstream from a hydroelectric dam', Trans. Am. Fish. Soc., 124(6), 836-844.

Valett, H. M. and Stanford, J. A. 1987. 'Food quality and hydropsychid caddisfly density in a lake outlet stream in Glacier National Park, Montana, USA', Can. J. Fish. Aquat. Sci., 44, 77-82.

Van Dijk, G. M., Marteijn, E. C. L. and Schulte-Wülwer-Leidig, A. 1995. 'Ecological rehabilitation of the River Rhine: plans, progress and perspectives', Regul. Riv., 11(34), 377--388.

Vannote, R. L. and Sweeney, B. W. 1980. 'Geographic analysis of thermal equilibria; a conceptual model for evaluating the effect of natural and modified thermal regimes on aquatic insect communities', American Naturalist, 115(5), 667-695.

Vannote, R. L., Minshall, G. W., Cummins, K. W., Sedell, J. R. and Cushing, C. E. 1980. 'The river continuum concept', Can. J. Fish. Aquat. Sci., 37(1), 130-137.

Ward, J. V. 1984. 'Stream regulation of the upper Colorado River: Channel configuration and thermal heterogeneity', Verh. Int. Verein. Theor. Angew. Limnol., 22, 1862-1866.

Ward, J. V. 1985. 'Thermal characteristics of running waters', Hydrobiologia, 125, 31-46.

Ward, J. V. in press. 'Riverine landscapes: biodiversity patterns, disturbance regimes and aquatic conservation', Biol. Conserv. 
Ward, J. V. and Dufford, R. G. 1979. 'Longitudinal and seasonal distribution of macroinvertebrates and epilithic algae in a Colorado springbrook-pond system', Arch. Hydrobiologia, 86(3), 284-321.

Ward, J. V. and Stanford, J. A. (Ed), 1979. The Ecology of Regulated Streams. Plenum Press, New York. 398 pp.

Ward, J. V. and Stanford, J. A. 1982. 'Thermal responses in the evolutionary ecology of aquatic insects', Ann. Rev. Entomol., $27,97-117$.

Ward, J. V. and Stanford, J. A. 1983a. 'The serial discontinuity concept of lotic ecosystems', in Fontaine III, T. D. I. and Bartell, S. M. (Eds), Dynamics of Lotic Ecosystems. Ann Arbor Science Publishers, Ann Arbor. pp. 29-42.

Ward, J. V. and Stanford, J. A. 1983b. 'The intermediate-disturbance hypothesis: An explanation for biotic diversity patterns in lotic ecosystems', in Fontaine III, T. D. and Bartell, S. M. (Eds), Dynamics of Lotic Ecosystems. Butterworth, Kent.

Ward, J. V. and Stanford, J. A. 1987. 'The ecology of regulated streams: Past accomplishments and directions for future research', in Craig, J. F. and Kemper, J. B. (Eds.), Regulated Streams-Advances in Ecology. Plenum, New York.

Ward, J. V. and Stanford, J. A. 1991. 'Benthic faunal patterns along the longitudinal gradient of a Rocky Mountain river system', Verh. Intern. Verein. Theor. Angew. Limnol., 24, 3087-3094.

Ward, J. V. and Stanford, J. A. 1995a. 'Ecological connectivity in alluvial river ecosystems and its disruption by flow regulation', Regul. Riv., 11, 105-120.

Ward, J. V. and Stanford, J. A. 1995b. 'The serial discontinuity concept: extending the model to floodplain rivers', Regul. Riv., 10, 159168.

Ward, J. V. and Voelz, N. J. 1988. 'Downstream effects of a large, deep-release, high mountain reservoir on lotic zoobenthos', Verh. Internat. Verein. Theor. Angew. Limnol., 23, 1174-1178.

Ward, J. V. and Wiens, J. A in press. 'Ecotones of riverine ecosystems: role and typology, spatio-temporal dynamics, and river regulation', in Zalewksi, M., F. Schiemer and Thorpe, J. (Eds), Inland Water Ecotones. Cambridge University Press, Cambridge.

Warren, C. E. 1971. Biology and Water Pollution Control. W. B. Saunders, Philadelphia. 434 pp.

Warren, C.E., Allen, M.J. and Haefner, J.W. 1979. 'Conceptual frameworks and the philisophical foundations of general living systems theory', Behavioral Science, 24, 296-310.

Waters, T. F. 1995. Sediment in Streams: Sources, Biological Effects and Control. American Fisheries Society, Bethesda. $251 \mathrm{pp}$.

Waters, T. F., Doherty, M. T. and Krueger, C. C. 1990. 'Annual production and production: biomass ratios for three species of stream trout in Lake Superior tributaries', Trans. Am. Fish. Soc., 119, 470-474.

Weisberg, S. B., Janicki, A. J., Gerritsen, J. and Wilson, H. T. 1990. 'Enhancement of benthic macroinvertebrates by minimum flow from a hydroelectric dam', Regul. Riv., 5, 265-277.

Welcomme, R. L. 1979. Fisheries Ecology of Floodplain Rivers. Longman. 317 pp.

Welcomme, R. L. 1995. 'Relationships between fisheries and the integrity of river systems', Reg. Riv., 11(1), 121-136.

Wissmar, R. C., Smith, J. E., McIntosh, B. A., Li, H. W., Reeves, G. H. and Sedell, J. R. 1994. 'A history of resource use and disturbance in riverine basins of eastern Oregon and Washington (early 1800s-1990s)', Northwest Sci., 68, 1-35.

Wooton, R. S. 1987. 'The ecology of lake-outlet black flies', in Kim, K. C. and Merritt, R. W. (Eds), Black Flies. The Pennsylvania State University, University Park, Pennsylvania. pp. 146-154.

Zwick, P. 1992. 'Stream habitat fragmentation - a threat to biodiversity', Biodiversity Conservation, 1, 80-97. 